Prepared in cooperation with the U.S. Environmental Protection Agency

Estimated Loads of Suspended Sediment and Selected Trace Elements Transported through Milltown Reservoir in the Upper Clark Fork Basin, Montana, Water Years 2004-07

Scientific Investigations Report 2008-5080

U.S. Department of the Interior U.S. Geological Survey 
Cover photograph: Clark Fork below Milltown Dam. Photograph by John Lambing, U.S. Geological Survey, taken May 1989. 


\section{Estimated Loads of Suspended Sediment and Selected Trace Elements Transported through Milltown Reservoir in the Upper Clark Fork Basin, Montana, Water Years 2004-07}

By John H. Lambing and Steven K. Sando

Prepared in cooperation with the U.S. Environmental Protection Agency

Scientific Investigations Report 2008-5080 


\section{U.S. Department of the Interior DIRK KEMPTHORNE, Secretary}

\section{U.S. Geological Survey \\ Mark D. Myers, Director}

\section{U.S. Geological Survey, Reston, Virginia: 2008}

For product and ordering information:

World Wide Web: http://www.usgs.gov/pubprod

Telephone: 1-888-ASK-USGS

For more information on the USGS — the Federal source for science about the Earth, its natural and living resources, natural hazards, and the environment:

World Wide Web: http://www.usgs.gov

Telephone: 1-888-ASK-USGS

Any use of trade, product, or firm names is for descriptive purposes only and does not imply endorsement by the U.S. Government.

Although this report is in the public domain, permission must be secured from the individual copyright owners to reproduce any copyrighted materials contained within this report.

Suggested citation:

Lambing, J.H., and Sando, S.K., 2008, Estimated loads of suspended sediment and selected trace elements transported through Milltown Reservoir in the upper Clark Fork basin, Montana, water years 2004-07: U.S. Geological Survey Scientific Investigations Report 2008-5080, 24 p. 


\section{Contents}

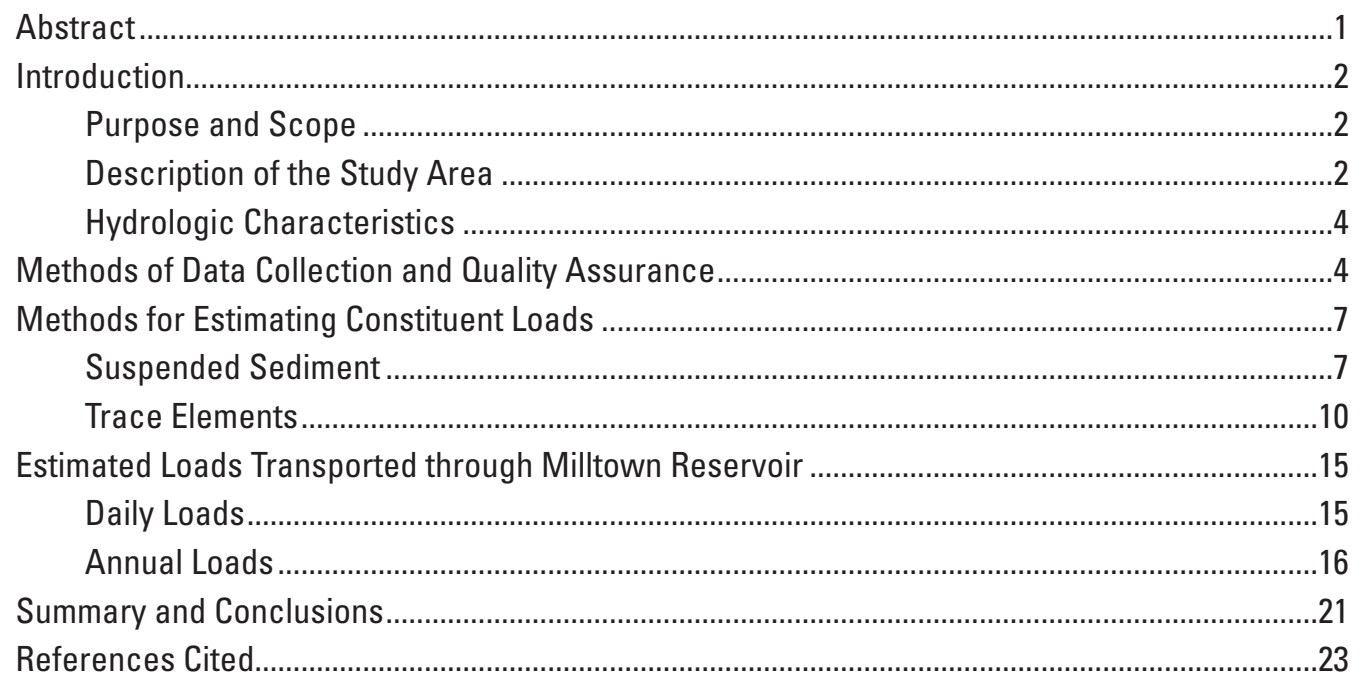

\section{Figures}

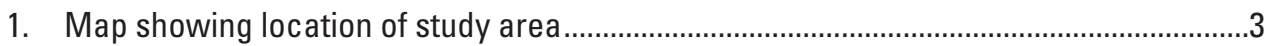

2-7. Graphs showing:

2. Daily mean streamflow for the study period and selected exceedance percentiles of long-term daily mean streamflow for Clark Fork above Missoula, Mont.

3. Relations between suspended-sediment discharge and streamflow before and after June 1, 2006, water years 2004-07....

4. Relations between unfiltered-recoverable copper discharge and suspended-sediment discharge before and after June 1, 2006, water years 2004-07.

5. Relations between unfiltered-recoverable iron discharge and suspended-sediment discharge before and after June 1, 2006, water years 2004-07.

6. Daily mean streamflow and estimated daily suspended-sediment loads transported to and from Milltown Reservoir, water years 2004-07

7. Daily mean streamflow and estimated daily unfiltered-recoverable copper loads transported to and from Milltown Reservoir, water years 2004-07 


\section{Tables}

1. Annual and peak streamflow characteristics for the study period, the period of continuous-streamflow records, and the period of peak-streamflow records for Clark Fork above Missoula, Mont

2. Equations for estimating suspended-sediment discharge for Clark Fork at Turah Bridge, near Bonner, Mont., Blackfoot River near Bonner, Mont., and Clark Fork above Missoula, Mont., water years 2004-07.

3. Equations for estimating unfiltered-recoverable trace-element discharge for Clark Fork at Turah Bridge, near Bonner, Mont., water years 2004-07.

4. Equations for estimating unfiltered-recoverable trace-element discharge for Blackfoot River near Bonner, Mont., water years 2004-07.

5. Equations for estimating unfiltered-recoverable trace-element discharge for Clark Fork above Missoula, Mont., water years 2004-07.

6. Annual mean streamflow and estimated annual loads and annual mass balance of suspended sediment and unfiltered-recoverable trace elements transported to and from Milltown Reservoir, water years 2004-07.

\section{Conversion Factors, Datum, Abbreviated Units, and Acronyms}

\begin{tabular}{lll}
\hline Multiply & \multicolumn{1}{c}{ By } & To obtain \\
\hline acre & 0.4047 & hectare $(\mathrm{ha})$ \\
cubic inch $\left(\mathrm{in}^{3}\right)$ & 0.01639 & liter $(\mathrm{L})$ \\
cubic yard $\left(\mathrm{yd}^{3}\right)$ & 0.7647 & cubic meter $\left(\mathrm{m}^{3}\right)$ \\
cubic foot per second $\left(\mathrm{ft}^{3} / \mathrm{s}\right)$ & 0.02832 & cubic meter per second $\left(\mathrm{m}^{3} / \mathrm{s}\right)$ \\
foot $(\mathrm{ft})$ & 0.3048 & meter $(\mathrm{m})$ \\
pound, avoirdupois $(\mathrm{lb})$ & 0.4536 & kilogram $(\mathrm{kg})$ \\
square mile $\left(\mathrm{mi}^{2}\right)$ & 2.590 & square kilometer $\left(\mathrm{km}^{2}\right)$ \\
ton, short $(2,000 \mathrm{lb})$ & 0.9072 & megagram $(\mathrm{Mg})$ \\
ton per day $(\mathrm{ton} / \mathrm{d})$ & 0.9072 & metric ton per day \\
ton per year $($ ton/yr) & 0.9072 & metric ton per year \\
\hline
\end{tabular}

Horizontal coordinate information is referenced to the North American Datum of 1927 (NAD 27).

Water year is the 12-month period from October 1 through September 30 of the following calendar year. The water year is designated by the calendar year in which it ends. For example, water year 2007 is the period from October 1, 2006, through September 30, 2007. 


\section{Abbreviated water-quality units used in this report:}

$\mu \mathrm{g} / \mathrm{L} \quad$ micrograms per liter

$\mathrm{mg} / \mathrm{L} \quad$ milligrams per liter

\section{Acronyms used in this report:}

$\begin{array}{ll}\text { ASO } & \text { arsenic discharge } \\ \text { CDO } & \text { cadmium discharge } \\ \text { CUO } & \text { copper discharge } \\ \text { FEO } & \text { iron discharge } \\ \text { LOG } & \text { logarithm (base 10) } \\ \text { LOWESS } & \text { locally weighted scatter plot smoothing } \\ \text { LRL } & \text { laboratory reporting level } \\ \text { MNO } & \text { manganese discharge } \\ \text { NPL } & \text { National Priorities List } \\ \text { NWIS } & \text { National Water Information System } \\ \text { NWOL } & \text { National Water Quality Laboratory } \\ \text { PBO } & \text { lead discharge } \\ \text { p-value } & \text { significance level } \\ \text { R } & \text { coefficient of determination } \\ \text { RBCF } & \text { retransformation-bias-correction factor } \\ \text { RSD } & \text { relative standard deviation } \\ \text { SE } & \text { standard error of estimate } \\ \text { SEDO } & \text { suspended-sediment discharge } \\ \text { USEPA } & \text { U.S. Environmental Protection Agency } \\ \text { USGS } & \text { U.S. Geological Survey } \\ \text { ZNO } & \text { zinc discharge }\end{array}$





\title{
Estimated Loads of Suspended Sediment and Selected Trace Elements Transported through Milltown Reservoir in the Upper Clark Fork Basin, Montana, Water Years 2004-07
}

\author{
By John H. Lambing and Steven K. Sando
}

\begin{abstract}
The purpose of this report is to present estimated daily and annual loads of suspended sediment and selected trace elements for water years 2004-07 at two sites upstream and one site downstream from Milltown Reservoir. Milltown Reservoir is a National Priorities List Superfund site in the upper Clark Fork basin of western Montana where sediments enriched in trace elements from historical mining and ore processing have been deposited since the construction of Milltown Dam in 1907. The estimated loads were used to quantify annual net gains and losses (mass balance) of suspended sediment and trace elements within Milltown Reservoir before and after June 1, 2006, which was the start of Stage 1 of a permanent drawdown of the reservoir in preparation for removal of Milltown Dam. This study was done in cooperation with the U.S. Environmental Protection Agency.

Daily loads of suspended sediment were estimated for water years 2004-07 by using either high-frequency sampling as part of daily sediment monitoring or regression equations relating suspended-sediment discharge to streamflow. Daily loads of unfiltered-recoverable arsenic, cadmium, copper, iron, lead, manganese, and zinc were estimated by using regression equations relating trace-element discharge to suspended-sediment discharge. Regression equations were developed from data for periodic water-quality samples collected during water years 2004-07. The equations were applied to daily records of either streamflow or suspendedsediment discharge to produce estimated daily loads.

Variations in daily suspended-sediment and trace-element loads generally coincided with variations in streamflow. For most of the period before June 1, 2006, differences in daily loads transported to and from Milltown Reservoir were minor or indicated small amounts of deposition; however, losses of suspended sediment and trace elements from the reservoir occurred during temporary drawdowns in July-August 2004 and October-December 2005. After the start of Stage 1 of the permanent drawdown on June 1, 2006, losses of suspended
\end{abstract}

sediment and trace elements from the reservoir persisted for all streamflow conditions during the entire interval of the Stage 1 drawdown (June 1, 2006-September 30, 2007) within the study period.

Estimated daily loads of suspended sediment and trace elements were summed for each year to produce estimated annual loads used to determine the annual net gains (deposition) or losses (erosion) of each constituent within Milltown Reservoir during water years 2004-07. During water year 2004 , there was an annual net gain of suspended sediment in the reservoir. The annual net gains and losses of trace elements were inconsistent in water year 2004, with gains occurring for arsenic and iron, but losses occurring for cadmium, copper, lead, manganese, and zinc. In water year 2005, there were annual net gains of suspended sediment and all the trace elements within the reservoir. In water year 2006, there were annual net losses of all constituents from the reservoir, likely as the result of sediment erosion from the reservoir during both a temporary drawdown in October-December 2005 and Stage 1 of the permanent drawdown that continued after June 1, 2006. In water year 2007, when the Stage 1 drawdown was in effect for the entire year, there were large annual net losses of suspended sediment and trace elements from the reservoir. The annual net losses of constituents from Milltown Reservoir in water year 2007 were the largest of any year during the 2004-07 study period. In water year 2007, the annual net loss of suspended sediment from the reservoir was 130,000 tons, which was more than double (about 222 percent) the combined inflow to the reservoir. The largest annual net losses of trace elements in water year 2007, in percent of the combined inflow to the reservoir, occurred for cadmium, copper, lead, and zinc - about 190 percent for cadmium, 170 percent for copper, 150 percent for lead, and 238 percent for zinc. The large annual net losses of suspended sediment and trace elements in water year 2007 indicate that much of the constituent load transported from Milltown Reservoir was derived from eroded reservoir sediment, rather than from upstream sources. 


\section{Introduction}

Milltown Reservoir is located on the Clark Fork at the confluence of the Clark Fork and Blackfoot River in western Montana (fig. 1). The reservoir is formed by Milltown Dam, which was constructed in 1907 to supply hydroelectric power. Historical large-scale mining and ore processing in the upper Clark Fork basin produced large quantities of tailings enriched with trace elements such as arsenic, cadmium, copper, lead, and zinc. Tailings have been eroded and transported downstream along the Clark Fork, contaminating the approximately 6.6 million $\mathrm{yd}^{3}$ of sediment that has accumulated in Milltown Reservoir (U.S. Environmental Protection Agency, 2004). Potential toxicity from the elevated trace-element concentrations in water and bed sediment led to the designation of Milltown Reservoir and upstream reaches of the Clark Fork as an extended National Priorities List (NPL) Superfund site in 1983 (U.S. Environmental Protection Agency, 2004).

As part of remediation planning associated with the Superfund process, the U.S. Environmental Protection Agency (USEPA) issued a record of decision in December 2004 that included removal of Milltown Dam as one of the remedial activities (U.S. Environmental Protection Agency, 2004). To accommodate various construction activities and the excavation of a portion of the reservoir bottom sediments prior to dam removal, the initial phase (Stage 1) of a permanent drawdown of the reservoir to a lower pool level began on June 1, 2006. The Stage 1 drawdown lowered the average summer pool by about 10-12 ft. Two subsequent phases of drawdown (Stages 2 and 3) are planned to eventually lower the reservoir pool an additional $17 \mathrm{ft}$ (for a total drawdown of about $29 \mathrm{ft}$ ) to allow access for removal of the powerhouse and spillway (U.S. Environmental Protection Agency, written commun., September 2007).

Because of the large quantity of contaminated sediment that has been deposited in Milltown Reservoir, there was concern regarding an increased potential for scour of bottom sediments and associated trace elements from the shallow reservoir after the start of the Stage 1 drawdown, especially during high streamflow. To address this concern, the USEPA initiated a program of intensive sampling by the U.S. Geological Survey (USGS) during water years 2006 and 2007 to supplement the routine sampling of the long-term monitoring program (Dodge and others, 2007). The supplemental sampling was conducted during the April-June periods of high streamflow and during selected periods of reservoir drawdown to provide additional resolution on variations in water quality and constituent transport through Milltown Reservoir. The supplemental sampling is planned to continue through the completion of all three stages of the permanent drawdown and dam removal (U.S. Environmental Protection Agency, written commun., 2008).

The USGS, in cooperation with the USEPA, estimated daily constituent loads transported at two sites upstream and one site downstream from Milltown Reservoir by using periodic water-quality, daily streamflow, and daily suspendedsediment data. Estimated annual loads were obtained by summing estimated daily loads and were used to determine the annual mass balance of suspended sediment and selected trace elements transported through Milltown Reservoir during water years 2004-07 (October 1, 2003, through September 30, 2007).

\section{Purpose and Scope}

The purpose of this report is to present estimated daily and annual loads of suspended sediment and selected trace elements (unfiltered-recoverable arsenic, cadmium, copper, iron, lead, manganese, and zinc) for water years 2004-07 at two sites upstream and one site downstream from Milltown Reservoir (fig. 1). The estimated loads are used to quantify annual net gains and losses (mass balance) of suspended sediment and trace elements within Milltown Reservoir before and after June 1, 2006 (start of Stage 1 of the permanent drawdown of the reservoir). The methods used to estimate loads and the characteristics of daily and annual loads transported to and from Milltown Reservoir are described.

The USGS has collected periodic water-quality samples, as well as daily streamflow and suspended-sediment data, at each of the three sites as part of Clark Fork monitoring programs (Dodge and others, 2005; Dodge and others, 2006; and Dodge and others, 2007). The periodic water-quality, daily streamflow, and daily suspended-sediment data used to develop regression equations and estimate loads are publicly accessible on the USGS National Water Information System (NWIS) Web site for Montana (http://waterdata.usgs.gov/mt/ nwis).

\section{Description of the Study Area}

The Clark Fork basin upstream from Milltown Dam (fig. 1) drains an area of about 6,000 $\mathrm{mi}^{2}$. Milltown Reservoir is a small impoundment of about 540 acres formed by Milltown Dam at the confluence of the Clark Fork and Blackfoot River. The reservoir is at the downstream end of a contiguous complex of NPL Superfund sites extending from the headwaters of Silver Bow Creek near Butte to Milltown Dam near Missoula (U.S. Environmental Protection Agency, 2004).

Two monitoring sites upstream from Milltown Reservoir (Clark Fork at Turah Bridge, near Bonner, station 12334550; and Blackfoot River near Bonner, station 12340000) represent the combined input of streamflow and constituent load to the reservoir; one site downstream from Milltown Reservoir (Clark Fork above Missoula, station 12340500) represents the output from the reservoir. For brevity, Clark Fork at Turah Bridge, near Bonner will be referred to as Clark Fork at Turah Bridge in this report. Milltown Reservoir is considered a "run of the river" reservoir because streamflow leaving the reservoir is equal to the streamflow of the Clark Fork and Blackfoot 


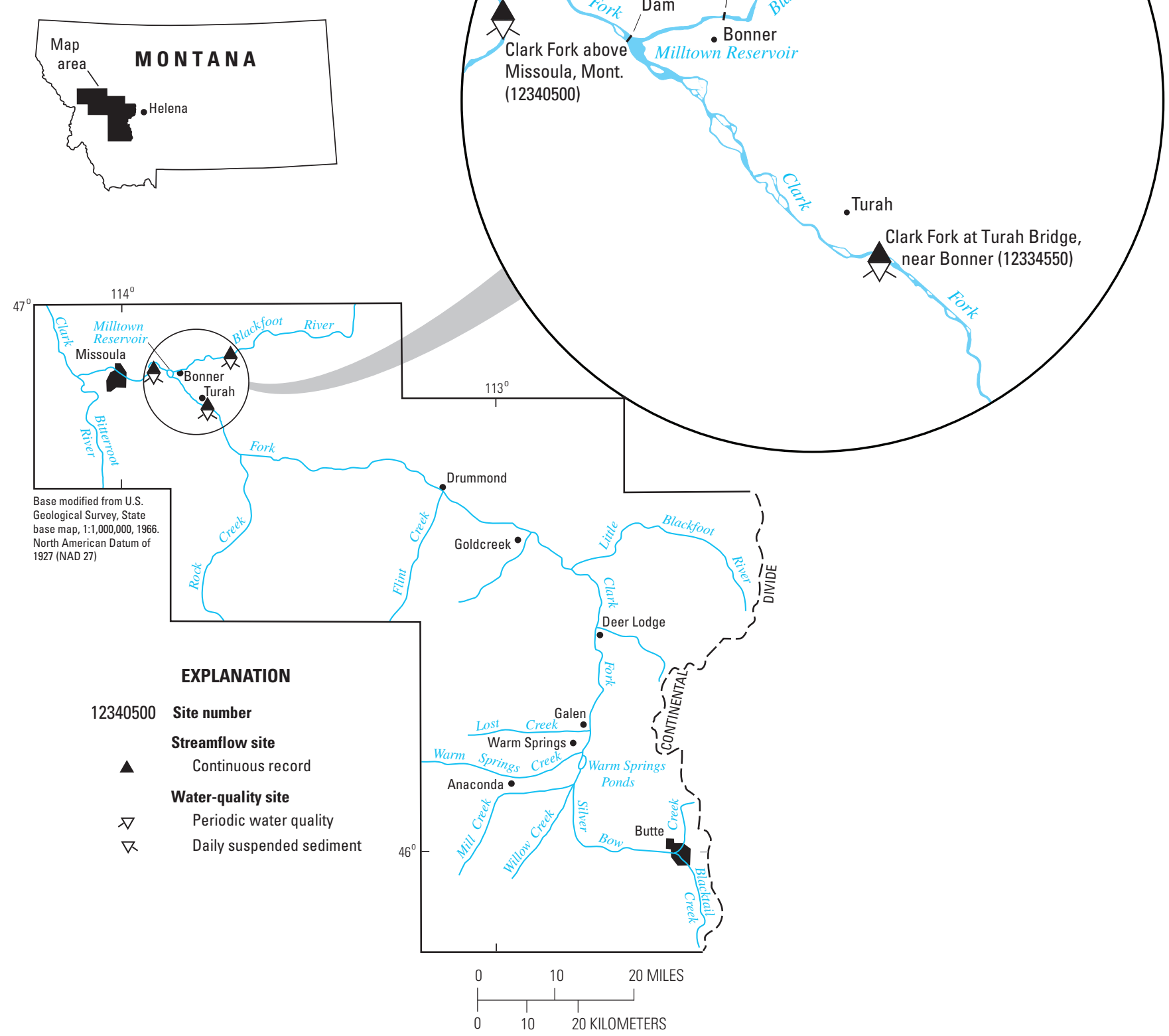

Figure 1. Location of study area. 
River entering the reservoir (U.S. Environmental Protection Agency, written commun., 2003).

\section{Hydrologic Characteristics}

Streamflow magnitude is a predominant factor affecting the transport of suspended sediment and sediment-associated constituents through a watershed. Streamflow magnitude can affect both the sustained delivery of constituent loads from the watershed and also the capacity to locally scour bottom sediments within Milltown Reservoir. The hydraulic energy associated with peak flows is especially important relative to the scour of bottom sediments in shallow water bodies, such as Milltown Reservoir. Because streamflow can vary substantially from year to year, thereby affecting rates of constituent transport, comparison of streamflow during the 2004-07 study period to a long-term period of record allows recent hydrologic conditions to be placed in a historical perspective.

The reference station with the longest period of record available for comparison to streamflow during the study period is Clark Fork above Missoula, with 78 years (water years 1930-2007) of continuous-streamflow record (http:// waterdata.usgs.gov/mt/nwis). The variation in daily mean streamflow at Clark Fork above Missoula during water years 2004-07 is shown in figure 2, along with selected long-term streamflow characteristics for water years 1930-2007 to illustrate differences between recent and long-term hydrologic conditions.

The long-term streamflow characteristics at Clark Fork above Missoula (fig. 2) are represented by selected exceedance percentiles (10th, 50th, and 90th) of daily mean streamflow during the period of record. An exceedance percentile indicates the magnitude of daily mean streamflow that was exceeded the given percent of time on a specific day of the year during the long-term period of record. For example, the 10th exceedance percentile of long-term daily mean streamflow represents a relatively high streamflow magnitude that was exceeded only 10 percent of the time on that specific day of the year (for example, on all of the October 1 dates, October 2 dates, and so on) during the period of record. Exceedance percentiles are determined for each day of the year for all the years during the period of record to produce a long-term annual hydrograph of daily mean streamflows representing a particular exceedance percentile. For relative comparison of streamflow during the study period to long-term streamflow, "normal" is indicated by the 50th exceedance percentile, or median.

Streamflows during water years 2004-07 (fig. 2) generally were below or near normal at Clark Fork above Missoula. The departures from normal flow can be misleading when viewing a graph plotted on a logarithmic scale; therefore, the proximity of the daily mean streamflow during the study period to the 10th (high flow) and 90th (low flow) exceedance percentile lines offer additional insight to the magnitude of the departure. Although the annual peak flows were near normal in every year except 2004 (in which peak flow was below normal), the receding limb of the hydrograph following the annual peak flow occurred sooner in most years during water years 2004-07 relative to long-term conditions and typically decreased to a below-normal streamflow during the summer. The shift towards earlier occurrence of the falling limb is most notable for water years 2006 and 2007, and is matched by an earlier occurrence of the rising limb during the spring of 2006 and 2007. The earlier occurrence of the rising limb resulted in short periods of time when streamflow exceeded the median, and sometimes the 10th exceedance percentile, of long-term streamflow. During water years 2004-07, streamflows in the summer decreased to below normal and at times decreased to magnitudes near or at the 90th exceedance percentile. Streamflows typically increased in the fall to near normal; however, the below-normal flows in the summer of 2006 and 2007 continued later into the fall than in previous years. Winter flows were erratic in most years, possibly due to variations in the duration and intensity of freezing conditions or snowfall amounts and runoff during periods of thawing. Despite the irregular winter flow conditions, a consistent pattern during the 2004-07 study period was that streamflows decreased to magnitudes substantially below the 90th exceedance percentile on several days during the winter in every year. Three days in 2005 (January 5 and December 7 and 8) and one day in 2007 (January 13) had the minimum recorded streamflows for those dates during the period of record at Clark Fork above Missoula (http://waterdata.usgs.gov/mt/nwis). In contrast, a large runoff event in November 2006 (fig. 2) resulted in three days (November 8-10) with the maximum recorded streamflows for those dates during the period of record.

Values of selected annual and peak streamflow characteristics for each year of the study period (water years 2004-07) and for the period of record (water years 1930-2007 for continuous-streamflow records; water years 1908, 1930-2007 for peak-streamflow records) are presented for Clark Fork above Missoula (table 1). Annual mean streamflows for every year of the study period were less than the long-term mean annual streamflow and ranged from 70 to 86 percent. Annual instantaneous peak streamflows during the study period also were less than the long-term mean annual peak streamflow and ranged from 47 to 83 .

\section{Methods of Data Collection and Quality Assurance}

Water-quality samples were collected periodically at the three sites near Milltown Reservoir for analysis of suspended sediment and trace elements. Samples were collected at a frequency of 6-8 times per year during water years 2004-07 as part of the long-term Clark Fork monitoring program (Dodge and others, 2007). During 2006 and 2007, additional samples were collected as part of a supplemental monitoring program for the lower Clark Fork basin to provide better resolution 


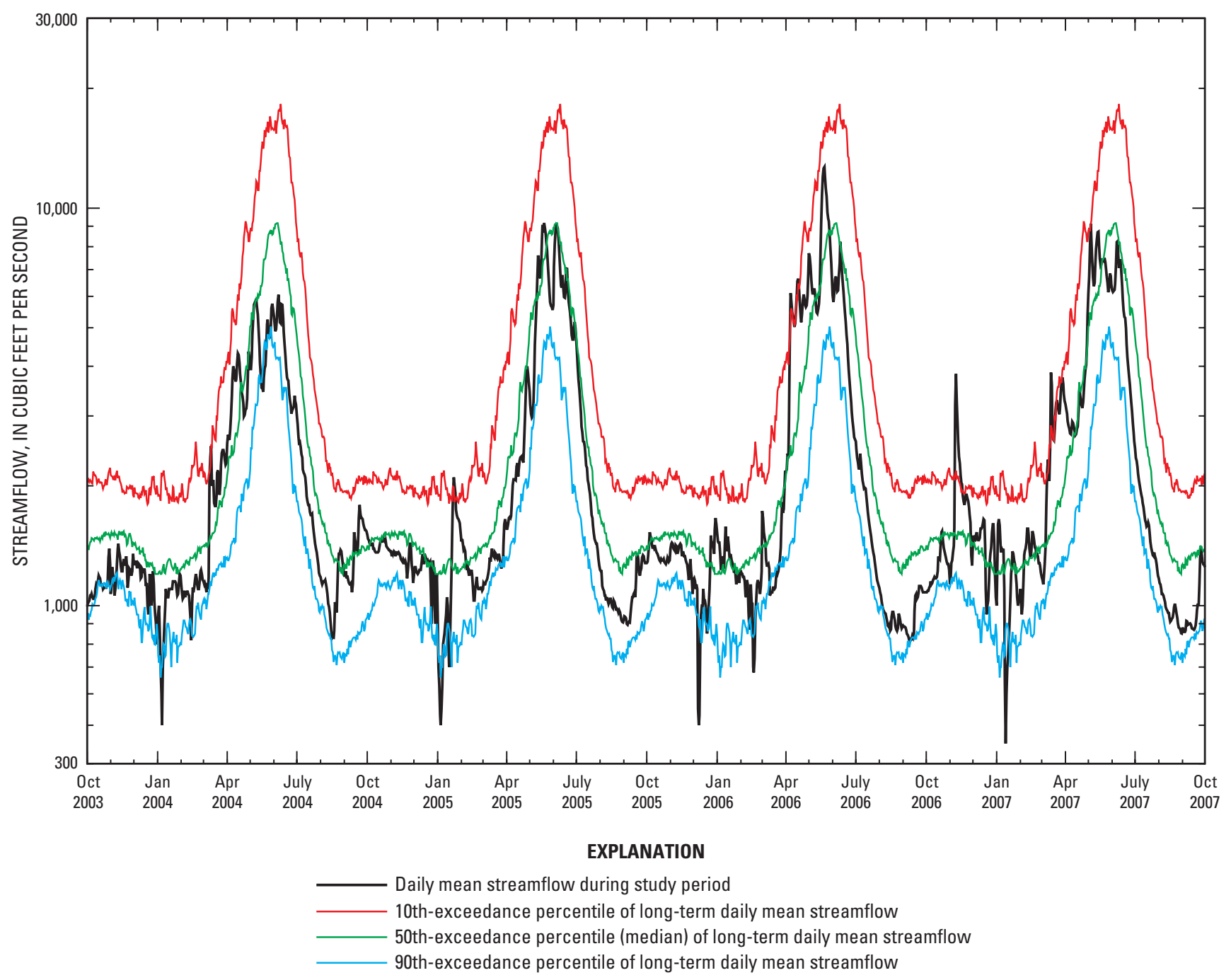

Figure 2. Daily mean streamflow for the study period (water years 2004-07) and selected exceedance percentiles of long-term (water years 1930-2007) daily mean streamflow for Clark Fork above Missoula, Mont.

of the potential effect of scour of bottom sediments from the reservoir, which resulted in a sampling frequency of about 16-20 times per year at each site (Dodge and others, 2007).

Periodic water-quality samples were collected throughout the entire stream depth at multiple locations across the stream by using depth- and width-integration methods described by Ward and Harr (1990), Edwards and Glysson (1999), and U.S. Geological Survey (variously dated). Sampling equipment consisted of depth-integrating suspended-sediment samplers (DH-81, D-74TM, and D-95), which were equipped with nylon nozzles and constructed of plastic or coated with a nonmetallic epoxy paint. Depth-integrating samplers are designed to sample the water column isokinetically, whereby velocity flow paths into the nozzle are not distorted and suspended particles enter the sample-collection bottle at the same concentration as in the surrounding water. The combination of sampling methods and depth-integrating sampling equipment provides a vertically and laterally discharge-weighted composite sample that is representative of the entire flow passing through the cross-sectional area of the stream. Samples were processed onsite according to procedures described by Ward and Harr (1990), Horowitz and others (1994), and U.S. Geological Survey (variously dated). Quality-assurance procedures for processing water-quality samples are described by U.S. Geological Survey (variously dated) and Lambing (2006).

Measurements of $\mathrm{pH}$, specific conductance, and water temperature were made onsite during all sampling visits. Instantaneous streamflow at the time of periodic water-quality sampling was determined either by direct measurement or from stage-discharge rating tables (Rantz and others, 1982).

All three sites near Milltown Reservoir were operated as continuous streamflow-gaging stations during water years 2004-07. Daily mean streamflow was determined by using the continuous record of stage and stage-discharge relations 
Table 1. Annual and peak streamflow characteristics for the study period (water years 2004-07), the period of continuous-streamflow records (water years 1930-2007), and the period of peak-streamflow records (water years 1908, 1930-2007) for Clark Fork above Missoula, Mont.

[Abbreviation: e, estimated]

\begin{tabular}{|c|c|c|c|c|c|c|}
\hline \multirow[b]{2}{*}{ Water year } & \multicolumn{3}{|c|}{ Annual streamflow } & \multicolumn{3}{|c|}{ Peak streamflow } \\
\hline & $\begin{array}{l}\text { Annual mean } \\
\text { streamflow } \\
\text { (cubic feet per } \\
\text { second) }\end{array}$ & $\begin{array}{l}\text { Percent of } \\
\text { long-term } \\
\text { mean annual } \\
\text { streamflow' }\end{array}$ & $\begin{array}{l}\text { Long-term } \\
\text { exceedance } \\
\text { percentile }{ }^{2} \text { for } \\
\text { annual mean } \\
\text { streamflow } \\
\text { (percent) }\end{array}$ & $\begin{array}{c}\text { Annual } \\
\text { instantaneous } \\
\text { peak streamflow } \\
\text { (cubic feet per } \\
\text { second) }\end{array}$ & $\begin{array}{c}\text { Percent of } \\
\text { long-term } \\
\text { mean annual } \\
\text { instantaneous } \\
\text { peak streamflow }{ }^{3}\end{array}$ & $\begin{array}{c}\text { Percent of } \\
\text { long-term } \\
\text { maximum annual } \\
\text { instantaneous } \\
\text { peak streamflow }\end{array}$ \\
\hline 2004 & 2,040 & 70 & 84 & 7,290 & 47 & 15 \\
\hline 2005 & 2,260 & 78 & 75 & 9,400 & 60 & 20 \\
\hline 2006 & 2,480 & 86 & 65 & 12,900 & 83 & 27 \\
\hline 2007 & 2,440 & 84 & 68 & e9,320 & 60 & 19 \\
\hline
\end{tabular}

${ }^{1}$ The long-term mean annual streamflow for the period of continuous-streamflow records (water years 1930-2007) is 2,900 cubic feet per second.

${ }^{2}$ The exceedance percentile indicates the percent of the time that the annual mean streamflow for the given year was exceeded during the long-term period of continuous-streamflow records (water years 1930-2007). For example, an exceedance percentile of 84 percent represents a relatively low streamflow condition that was exceeded 84 percent of the time during the long-term period of record.

${ }^{3}$ The long-term mean annual instantaneous peak streamflow for the period of peak-streamflow records (water years 1908, 1930-2007) for Clark Fork above Missoula, Mont. is 15,600 cubic feet per second.

${ }^{4}$ The long-term maximum annual instantaneous peak streamflow for the period of peak-streamflow records (water years 1908, 1930-2007) is 48,000 cubic feet per second, which occurred in 1908.

developed from periodic streamflow measurements according to procedures described by Rantz and others (1982). Clark Fork at Turah Bridge and Clark Fork above Missoula also were operated as daily sediment stations during the entire period of water years 2004-07; Blackfoot River near Bonner was operated as a daily sediment station only during water years 2006 and 2007. Suspended-sediment samples for the daily-sediment stations were collected at a high frequency (2-14 times per week) by local contract observers using depth integration at a single location near midstream. Quality-assurance procedures for generating daily records of streamflow and suspended-sediment data are described by White and others (1998). The quality of daily records were rated good to excellent, except for periods of ice cover, which were rated poor (Rantz and others, 1982).

Periodic water-quality samples were analyzed for suspended-sediment concentration and percent of suspended sediment finer than 0.062-mm diameter (http://waterdata. usgs.gov/mt/nwis) by the USGS Montana Water Science Center Sediment Laboratory (herein referred to as Montana Sediment Laboratory) in Helena, Mont. according to methods described by Guy (1969) and Dodge and Lambing (2006). Quality-assurance procedures used by the Montana Sediment Laboratory are described by Dodge and Lambing (2006).

Periodic water-quality samples were analyzed for traceelement concentrations (http://waterdata.usgs.gov/mt/hwis) by the USGS National Water Quality Laboratory (NWQL) in Denver, Colo. Concentrations of "unfiltered recoverable" (formerly referred to as "total recoverable") trace elements were determined from unfiltered samples that were first digested with dilute hydrochloric acid (Hoffman and others, 1996) and then analyzed by inductively coupled plasma-mass spectrometry (Garbarino and Struzeski, 1998). Unfiltered-recoverable concentrations represent the combined dissolved and particulate fractions of the trace element. Quality-assurance procedures used by the NWQL are described by Friedman and Erdmann (1982), Jones (1987), Pritt and Raese (1995), and Maloney (2005).

Quality-assurance data for periodic water-quality samples were obtained on an ongoing basis by analysis of qualitycontrol samples (blanks and replicates), which were submitted along with routine samples on every field trip. Analytical results for quality-control samples are used to evaluate the performance of sampling and analytical methods in order to ensure that results for environmental samples are reliable. Quality-assurance data for the Clark Fork sampling program during water years 2004-07 are reported in Dodge and others (2005, 2006, 2007, and Kent A. Dodge, U.S. Geological Survey, written commun., 2008).

Trace-element concentrations in blank samples collected during the 2004-07 study period were almost always less than the laboratory reporting level (LRL). Values exceeding twice the LRL were noted during data reviews to evaluate the presence of a consistent trend that could indicate systematic contamination. Values exceeding twice the LRL were infrequent and occurred sporadically, which indicated that there were no consistent trends of contamination bias that might affect the data for environmental samples. Therefore, no adjustments 
to trace-element concentrations were made during the study period on the basis of analytical results for blanks.

Precision for each trace element was determined by calculation of a relative standard deviation (RSD) for analytical results of replicate samples. The RSDs for all trace elements during the study period were within the 20-percent data quality objective of acceptable precision for concentrations in replicate samples.

\section{Methods for Estimating Constituent Loads}

The term "load" represents the mass (commonly expressed in tons or pounds) of a constituent transported past a sampling site during a specified period of time. Loads can be computed for various time increments, such as instantaneous, daily, monthly, seasonal, or annual. Instantaneous loads represent the mass transported at the specific sampling time, whereas daily, monthly, seasonal, and annual loads represent the cumulative mass transported over a prolonged period. The rate of load transport is commonly expressed as "discharge," which incorporates both the unit of mass and time increment (for example, tons per day or tons per year).

Annual loads generally are more informative than instantaneous loads measured at the time of sampling because they represent the cumulative transport of constituent mass during a year, and thereby incorporate the potentially large range of daily variations. Annual loads also are useful for evaluating differences in constituent transport among sites to identify source areas contributing substantial inputs. Differences in annual loads transported past sampling sites can result from differences in annual flow volumes, physical basin characteristics, current and historical land-use activities, and localized conditions that affect constituent supply or susceptibility to erosion.

Estimation of annual loads typically requires either highfrequency sampling or the use of statistical relations, such as regression equations, that can be applied to a daily record of a related variable to produce an estimated daily load. The daily loads estimated by such methods provide increased temporal resolution of variability within a year that can give added insight to the effects of streamflow variations, seasonal differences, or unique conditions associated with discrete events. The daily loads estimated for each day of the year then can be summed to provide an estimated annual load.

Equations used to mathematically describe statistical relations and estimate daily constituent loads were developed from data for periodic water-quality samples collected during water years 2004-07. Various forms of data transformation were examined to produce a linear distribution that could be adequately fit by an ordinary least squares regression line. Selection of the best data transformation was based on the ability to produce linear relations that were statistically significant at the 0.05 significance level $(\mathrm{p}$-value $<0.05)$ and that had a uniform distribution of residuals around the regression line. Also, the coefficient of determination $\left(\mathrm{R}^{2}\right)$ and standard error of estimate (SE), in percent, which are measures of the scatter of data points around the regression line, were used in conjunction with statistical significance and residual distribution to evaluate the relation and select the best form of regression equation.

For trace-element concentrations that were censored (reported as less-than the LRL), one-half of the minimum LRL used during the study period was substituted for purposes of plotting and analysis of statistical relations. Where a large percentage of values were censored, such as cadmium for samples collected at Blackfoot River near Bonner, the statistical relations and estimates of daily loads have a greater degree of uncertainty than loads estimated by using relations developed from uncensored data. Loads estimated from datasets with a large percentage of censored data can still provide a relative measure of constituent transport, but estimates of mass balance are potentially subject to greater error.

\section{Suspended Sediment}

Daily suspended-sediment loads for water years 2004-07 were estimated for each of the three sites near Milltown Reservoir (fig. 1) by using either high-frequency sampling or statistical relations. Daily suspended-sediment loads were estimated directly by high-frequency sampling as part of daily sediment monitoring for Clark Fork at Turah Bridge and Clark Fork above Missoula for the entire study period of water years 2004-07, and for Blackfoot River near Bonner for water years 2006 and 2007. A statistical relation between suspendedsediment discharge and streamflow was used to estimate daily suspended-sediment loads for Blackfoot River near Bonner for water years 2004 and 2005.

High-frequency suspended-sediment samples for daily sediment monitoring were collected by a contract observer 2-14 times per week; sampling frequency depended on streamflow conditions. The concentration data from observer samples characterized daily temporal variations needed for developing continuous-concentration curves. Daily mean suspended-sediment concentrations were determined from the continuous-concentration curves according to methods described by Porterfield (1972). The daily mean suspendedsediment concentrations then were multiplied by the daily mean streamflows (and a units-conversion constant) to generate a record of daily suspended-sediment loads (http:// waterdata.usgs.gov/ $\mathrm{mt} / \mathrm{nwis}$ ) for the periods of daily sediment monitoring.

Relations between suspended-sediment discharge and streamflow during water years 2004-07 were examined for all three sites to evaluate differences in sediment-transport characteristics between the two periods before and after June 1, 2006 (start of Stage 1 of the permanent drawdown of Milltown Reservoir). Separate relations were developed for the period before the Stage 1 drawdown (October 1, 2003-May 31, 2006) 
and the period during the Stage 1 drawdown (June 1, 2006September 30, 2007). Prior to developing the relations, the suspended-sediment concentration for each periodic waterquality sample was converted to an equivalent suspendedsediment discharge, in tons per day, according to the equation

$$
Q_{\text {sed }}=C_{\text {sed }} Q K
$$

where

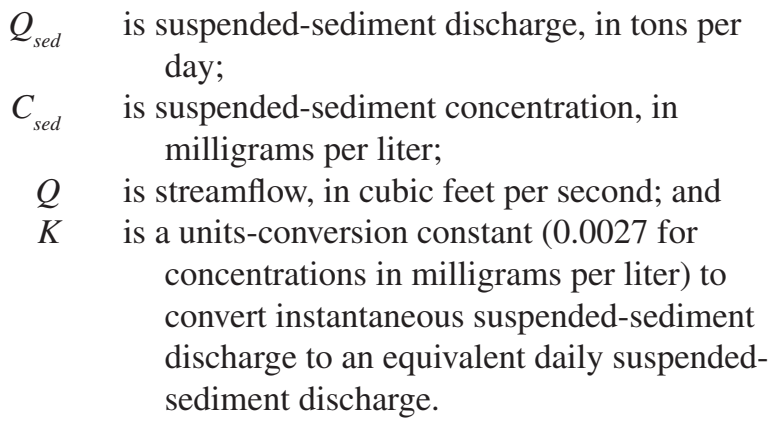

After suspended-sediment concentrations were converted to suspended-sediment discharges, plots of the relations between suspended-sediment discharge and streamflow for the two periods before and after June 1, 2006, were evaluated to identify changes in sediment-transport characteristics. Sediment-transport relations for water years 2004-07 are illustrated by scatter plots (fig. 3) that are fit with locally weighted scatter plot smoothing (LOWESS) lines (Cleveland and McGill, 1984; Cleveland, 1985) that show the central tendencies of the data distribution over the range of streamflows sampled during the two periods. The smooth lines do not imply statistically significant relations, but rather are used as a visual indication of differences in sediment-transport characteristics between the two periods.

The relations between suspended-sediment discharge and streamflow during water years 2004-07 for Clark Fork at Turah Bridge and Blackfoot River near Bonner (fig. $3 A$ and $3 B$ ) indicate no substantial change between the two periods (before and after June 1, 2006). Therefore, the sediment-transport relations for both periods at these two sites can be considered equivalent and can be described by a single regression equation. However, a notable shift in the sedimenttransport relation occurred at Clark Fork above Missoula (fig. 3C) after June 1, 2006. The relation during the Stage 1 drawdown was generally parallel and higher than the relation for the period prior to the Stage 1 drawdown, indicating that after June 1, 2006, a larger amount of suspended sediment was transported for a given streamflow throughout the entire range of streamflow conditions. This shift in sedimenttransport characteristics presumably was the result of either reservoir bottom sediment being more readily scoured by increased velocity as the depth of the overlying water in the reservoir decreased, or exposed sediment being eroded by channel cutting or bank collapse as water levels dropped and water drained from the material (U.S. Environmental Protection Agency, written commun., 2008). The eroded reservoir sediment contained a large proportion of sand, as indicated by a distinct change in particle-size distribution between the two periods for samples collected at Clark Fork above Missoula. The median percent of suspended sediment finer than 0.062 $\mathrm{mm}$ decreased from 84 percent in samples collected prior to June 1, 2006, to 42 percent for samples collected after June 1, 2006 (http://waterdata.usgs.gov/mt/nwis). As a result of the shift, it was determined that separate regression equations for the two periods before and after the start of the Stage 1 drawdown would more accurately describe the sediment-transport relations at Clark Fork above Missoula.

Regression equations for estimating suspended-sediment discharge from streamflow (table 2) provide a mathematical description of sediment-transport characteristics for all three sites. Statistical relations between suspended-sediment discharge and streamflow for periodic water-quality samples were developed by using ordinary least squares regression of data that were transformed to produce a linear distribution. Values for suspended-sediment discharge were transformed to base-10 logarithms $(\log )$ and streamflow values were transformed to cube roots $\left(\mathrm{Q}^{0.333}\right)$ to obtain the best linear distribution and least scatter. Single equations represent the entire 2004-07 study period for Clark Fork at Turah Bridge and Blackfoot River near Bonner; two equations describe the periods before and after June 1, 2006, for Clark Fork above Missoula.

The regression equations in table 2 are presented primarily for informational purposes. With the exception of water years 2004 and 2005 at the Blackfoot River near Bonner, the equations for estimating suspended-sediment discharge in table 2 were not used because daily sediment monitoring allowed direct estimation of daily sediment loads by high-frequency sampling. The equation for estimating suspended-sediment discharge for Blackfoot River near Bonner (table 2) was used only for water years 2004-05 when daily sediment monitoring was temporarily suspended. The equation was applied to the daily streamflow record to construct a daily record of estimated suspended-sediment loads. Daily suspended-sediment loads for Blackfoot River near Bonner for water years 2006 and 2007 were estimated directly by using high-frequency sampling after daily sediment monitoring was resumed in October 2005 (Dodge and others, 2007).

All the equations for estimating suspended-sediment discharge (table 2) are significant ( $\mathrm{p}$-value $<0.001)$. The relatively large $\mathrm{R}^{2}$ values indicate minor to moderate scatter of data around the regression line; SE ranged from 44.0 percent at Blackfoot River near Bonner to 66.2 percent at Clark Fork above Missoula for the period prior to the Stage 1 drawdown. Retransformation-bias-correction factors (RBCF) were determined for each of the equations to account for the systematic bias that can occur when data are transformed to log units for purposes of removing curvature in the distribution and then retransformed back to original arithmetic units to produce the final estimate (Koch and Smillie, 1986). To compensate for this log-transformation bias, retransformed results can be multiplied by a non-parametric bias-correction factor (Duan, 1983). In all cases, the retransformation bias was small; 


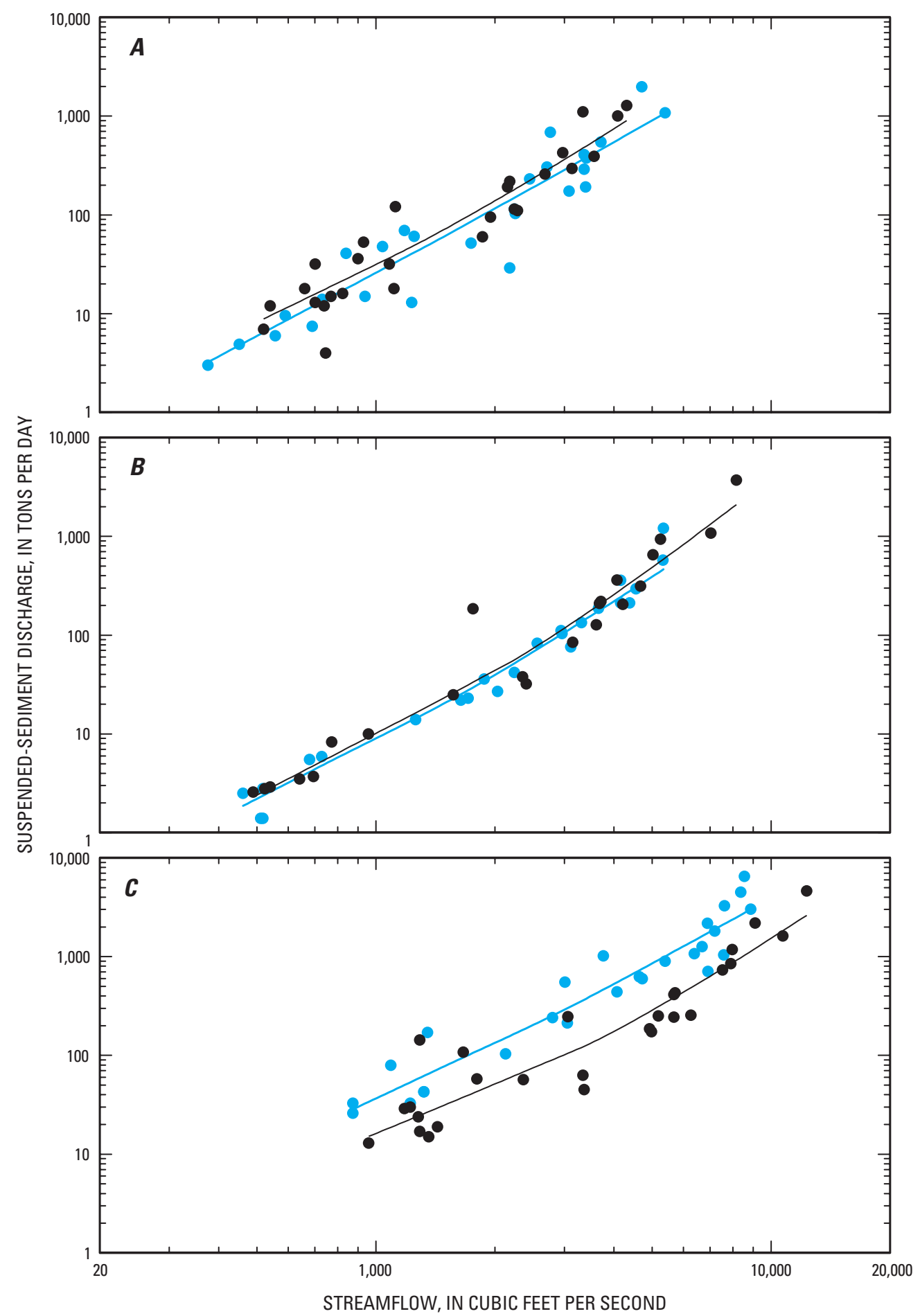

EXPLANATION

LOWESS smooth line for data collected during October 1, 2003-May 31, 2006

LOWESS smooth line for data collected during June 1, 2006-September 30, 2007

- Data collected during October 1, 2003-May 31, 2006

- Data collected during June 1, 2006-September 30, 2007

Figure 3. Relations between suspended-sediment discharge and streamflow before and after June 1, 2006 (start of Stage 1 of the permanent drawdown of Milltown Reservoir), water years 2004-07: A, Clark Fork at Turah Bridge, near Bonner, Mont.; B, Blackfoot River near Bonner, Mont.; and $C$, Clark Fork above Missoula, Mont. 
bias-correction factors ranged from 1.02 to 1.03 . The bias-correction factor used for regression-estimated daily suspendedsediment loads during water years 2004-05 at Blackfoot River near Bonner was 1.02 (table 2).

The equations for estimating suspended-sediment discharge (table 2) describe the relations only for the range of streamflow that was sampled at each site during water years 2004-07; therefore, extrapolation to higher streamflows might be subject to substantial error. More importantly, the two equations for Clark Fork above Missoula (downstream from Milltown Reservoir) represent two distinctly different sediment-transport conditions during periods before and after the start of the Stage 1 drawdown of Milltown Reservoir. The increased potential for localized erosion of reservoir sediment during the Stage 1 drawdown is subject to change as the permanent drawdown progresses through subsequent stages and various activities occur within construction areas. As a result, the separate equations for estimating suspended-sediment discharge at Clark Fork above Missoula are applicable only to the specific dates indicated in table 2 .

\section{Trace Elements}

Daily loads of unfiltered-recoverable trace elements for water years 2004-07 were estimated for each of the three sites near Milltown Reservoir (fig. 1) by using statistical relations developed from data for periodic water-quality samples collected during water years 2004-07. Relations between traceelement discharge and two related variables - streamflow and suspended-sediment discharge-were examined. Better relations for describing variation in trace-element discharge were obtained using suspended-sediment discharge as the explanatory variable. The better correlation is a result of the strong association between suspended-sediment concentrations and unfiltered concentrations of trace elements (Lambing, 1991). Suspended-sediment concentrations can vary substantially for a given streamflow magnitude due to differences in the soils and vegetative cover of areas where runoff occurs, seasonal and local differences in land use, and localized natural or human disturbances that cause sediment erosion. This variability in sediment supply, in turn, directly influences the concentration of sediment-associated trace elements, which can result in substantial variability in trace-element loads transported for a given streamflow. Therefore, accurate determination of suspended-sediment loads transported through Milltown Reservoir is important because it provides the basis for estimating trace-element loads transported through the reservoir.

Relations between trace-element discharge and suspended-sediment discharge for all three sites were examined for differences in trace-element transport characteristics between the two periods before and after the start of the Stage 1 drawdown of Milltown Reservoir. Prior to developing

Table 2. Equations for estimating suspended-sediment discharge for Clark Fork at Turah Bridge, near Bonner, Mont., Blackfoot River near Bonner, Mont., and Clark Fork above Missoula, Mont., water years 2004-07.

[Abbreviations: N, number of values; $\mathrm{R}^{2}$, coefficient of determination; p-value, significance level; SE, standard error of estimate, in percent; RBCF, retransformation-bias-correction factor; LOGSEDQ, base 10 logarithm of suspended-sediment discharge, in tons per day; Q, streamflow, in cubic feet per second; USGS, U.S. Geological Survey. Symbol: <, less than]

\begin{tabular}{|c|c|c|c|c|c|c|c|}
\hline Station & Period & Equation ${ }^{1}$ & $\mathbf{N}$ & $\mathbf{R}^{2}$ & p-value & SE & RBCF \\
\hline $\begin{array}{l}\text { Clark Fork at Turah Bridge } \\
\text { near Bonner, Mont. } \\
(12334550)\end{array}$ & Oct. 1, 2003-Sept. 30, 2007 & LOGSEDQ $=0.248\left(\mathrm{Q}^{0.333}\right)-1.08$ & 53 & 0.88 & $<0.001$ & 64.3 & 1.03 \\
\hline $\begin{array}{l}\text { Blackfoot River near Bonner, } \\
\text { Mont. }^{2}(12340000)\end{array}$ & Oct. 1, 2003-Sept. 30, 2007 & LOGSEDQ $=0.250\left(Q^{0.333}\right)-1.57$ & 46 & .96 & $<.001$ & 44.0 & 1.02 \\
\hline $\begin{array}{l}\text { Clark Fork above Missoula, } \\
\text { Mont. }^{3}(12340500)\end{array}$ & Oct. 1, 2003-May 31, 2006 & LOGSEDQ $=0.164\left(\mathrm{Q}^{0.333}\right)-0.363$ & 27 & .87 & $<.001$ & 66.2 & 1.03 \\
\hline $\begin{array}{l}\text { Clark Fork above Missoula, } \\
\text { Mont. }^{3}(12340500)\end{array}$ & June 1, 2006-Sept. 30, 2007 & LOGSEDQ $=0.179\left(\mathrm{Q}^{0.333}\right)-0.161$ & 26 & .91 & $<.001$ & 52.7 & 1.02 \\
\hline
\end{tabular}

${ }^{1}$ Equations are provided primarily for informational purposes. Daily suspended-sediment discharge for water years 2006-07 for Blackfoot River near Bonner, and for the entire study period for the other two stations were estimated directly by high-frequency sampling of the daily sediment monitoring program.

${ }^{2}$ Equation used to estimate daily suspended-sediment discharge for water years 2004-05 when daily sediment monitoring was temporarily suspended.

${ }^{3}$ Separate equations were developed for the periods before (October 1, 2003-May 31, 2006) and after (June 1, 2006-September 30, 2007) the permanent drawdown of Milltown Reservoir that began on June 1, 2006. Unlike the other two sites, the distinct shift in sediment-transport characteristics for Clark Fork above Missoula, after the start of the permanent drawdown (see fig. 3) warranted a new regression relation to mathematically describe the new conditions. 
the relations, the trace-element concentration for each periodic water-quality sample was converted to an equivalent traceelement discharge, in tons per day, according to the equation

$$
Q_{t e}=C_{t e} Q K
$$

where

$Q_{t e} \quad$ is trace-element discharge, in tons per day;

$C_{t e}$ is trace-element concentration, in micrograms per liter;

$Q \quad$ is streamflow, in cubic feet per second; and

$K$ is a units-conversion constant $(0.0000027$ for

concentrations in micrograms per liter) to convert instantaneous trace-element discharge to an equivalent daily traceelement discharge.

After trace-element concentrations were converted to trace-element discharges, the relations between trace-element discharge and suspended-sediment discharge for the two periods before and after June 1, 2006, were evaluated to identify changes in trace-element transport characteristics. Trace-element transport relations for water years 2004-07 are illustrated by scatter plots for unfiltered-recoverable copper discharge (fig. 4) and unfiltered-recoverable iron discharge (fig. 5) that are fit with LOWESS smooth lines (Cleveland and McGill, 1984; Cleveland, 1985) that show the central tendencies of the data distribution during the two periods. The smooth lines do not imply statistically significant relations, but rather are used as a visual indication of differences in traceelement transport characteristics between the two periods.

The relations between unfiltered-recoverable copper discharge and suspended-sediment discharge during water years 2004-07 (fig. 4) indicate no substantial change between the two periods before and after June 1, 2006, at any of the three sites. Similar transport relations for the two periods were prevalent for all the trace elements at Clark Fork at Turah Bridge and Blackfoot River near Bonner; therefore, the transport relations for all the trace elements for both periods at these two sites can be considered equivalent and described by single regression equations for the entire 2004-07 study period. In contrast, the relations between unfiltered-recoverable iron discharge and suspended-sediment discharge at Clark Fork above Missoula (fig. 5C) revealed a minor, but consistent, downward shift during the Stage 1 drawdown compared to the period before the Stage 1 drawdown. The geochemical or physical basis for the shift in iron-transport characteristics is not known, and such a shift was not clearly evident for the other trace-element transport relations at Clark Fork above Missoula. Although the downward shift in iron-transport characteristics at Clark Fork above Missoula was small, it was consistent enough to warrant development of separate regression equations to more accurately describe transport during the two periods. Separate equations also were developed for the two periods for the other trace elements at Clark Fork above Missoula to provide a consistent approach in estimating traceelement loads at this site.

Statistical relations between trace-element discharge and suspended-sediment discharge were developed by using ordinary least squares regression of data from periodic water-quality samples that were transformed to produce a linear distribution. Values of both trace-element discharge and suspended-sediment discharge were transformed to log units to obtain the best linear distribution and least scatter. The resulting regression equations for estimating unfilteredrecoverable trace-element discharge for Clark Fork at Turah Bridge, Blackfoot River near Bonner, and Clark Fork above Missoula for water years 2004-07 are presented in tables 3-5, respectively. Single equations for each trace element represent the entire 2004-07 study period at Clark Fork at Turah Bridge and Blackfoot River near Bonner; two equations represent the periods before and after June 1, 2006, for Clark Fork above Missoula.

All the equations for estimating trace-element discharge (tables 3-5) are significant ( $\mathrm{p}$-value $<0.001$ ). The large $\mathrm{R}^{2}$ values indicate relatively minor scatter of data around the regression line; however, the scatter increased slightly in the equations for Clark Fork above Missoula (table 5) during the Stage 1 drawdown compared to the period before the Stage 1 drawdown, possibly as a result of variations in localized erosion of sediment within Milltown Reservoir. The ranges of SE in the equations for all three sites were 20.0-34.5 percent for arsenic, 26.6-44.1 percent for cadmium, 30.3-44.9 percent for copper, 15.6-27.7 percent for iron, 21.2-43.3 percent for lead, 21.5-30.9 percent for manganese, and 23.6-43.8 percent for zinc.

The regression equations in tables 3-5 were applied to the daily record of estimated suspended-sediment loads to estimate daily trace-element loads for water years 2004-07. The retransformed results were multiplied by bias-correction factors to compensate for log-transformation bias by using procedures described by Duan (1983). Bias-correction factors were small in all cases and ranged from 1.00 to 1.02 .

The equations for estimating trace-element discharge in tables 3-5 describe the relations only for the range of streamflow that was sampled at each site during water years 2004-07; therefore, extrapolation to higher streamflows might be subject to substantial error. Similar to suspended-sediment discharge, the separate equations for the two periods before and after June 1, 2006, at Clark Fork above Missoula are applicable only to the specific dates indicated in table 5 . 


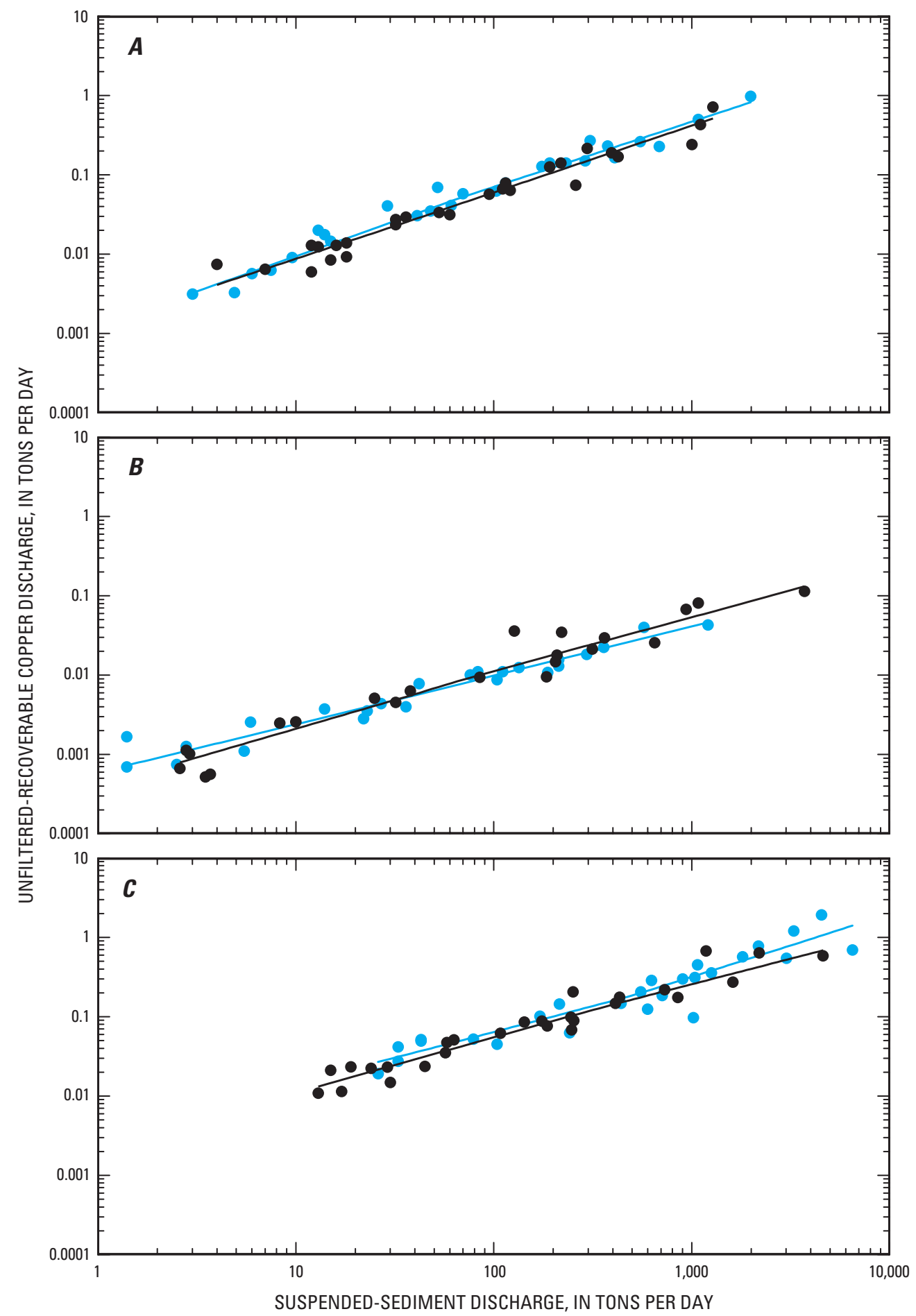

EXPLANATION

LOWESS smooth line for data collected during October 1, 2003-May 31, 2006 LOWESS smooth line for data collected during June 1, 2006-September 30, 2007

- Data collected during October 1, 2003-May 31, 2006

- Data collected during June 1, 2006-September 30, 2007

Figure 4. Relations between unfiltered-recoverable copper discharge and suspended-sediment discharge before and after June 1, 2006 (start of Stage 1 of the permanent drawdown of Milltown Reservoir), water years 2004-07: A, Clark Fork at Turah Bridge, near Bonner, Mont.; B, Blackfoot River near Bonner, Mont.; and $C$, Clark Fork above Missoula, Mont. 


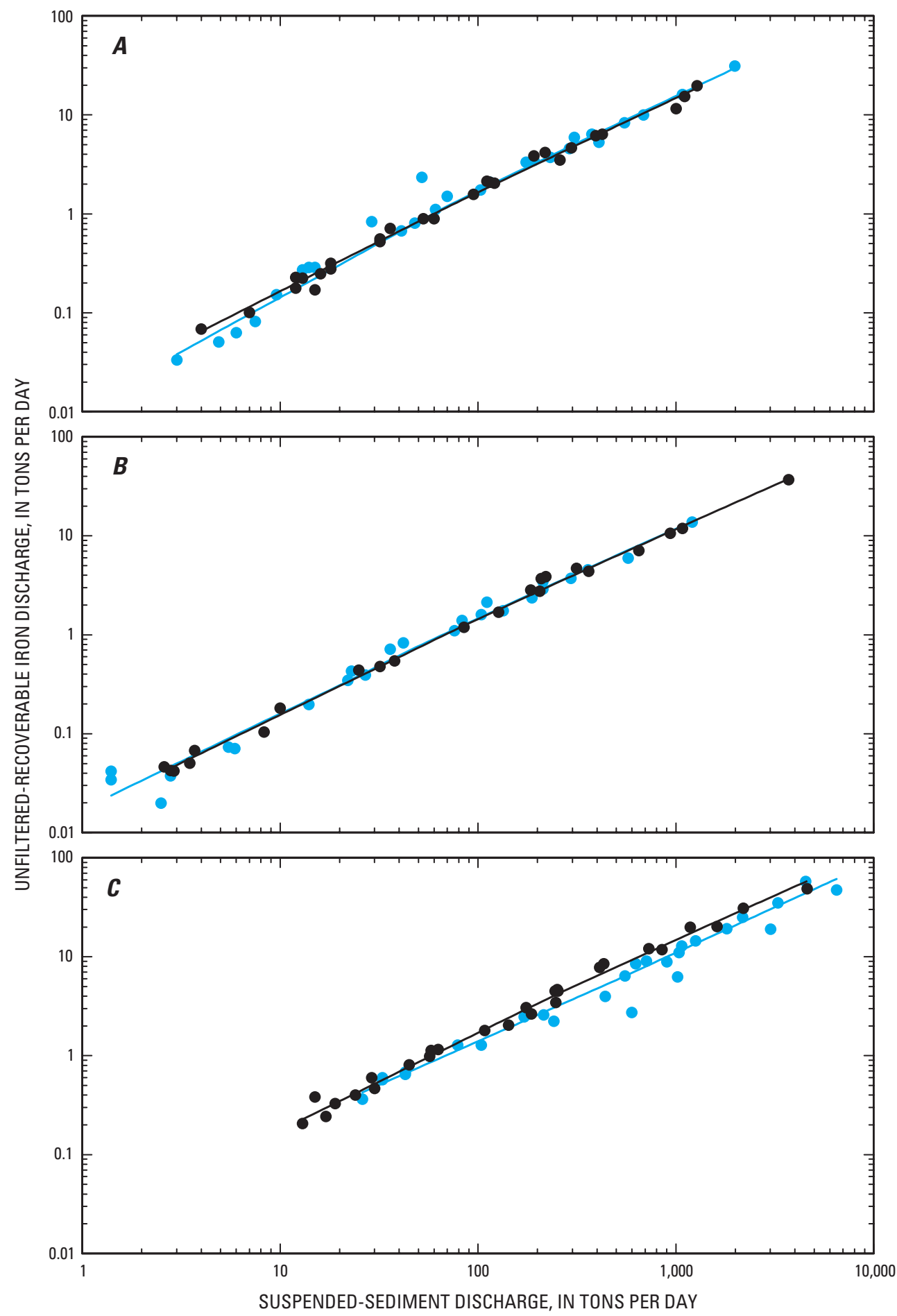

EXPLANATION

LOWESS smooth line for data collected during October 1, 2003-May 31, 2006

LOWESS smooth line for data collected during June 1, 2006-September 30, 2007

- Data collected during October 1, 2003-May 31, 2006

- Data collected during June 1, 2006-September 30, 2007

Figure 5. Relations between unfiltered-recoverable iron discharge and suspended-sediment discharge before and after June 1, 2006 (start of Stage 1 of the permanent drawdown of Milltown Reservoir), water years 2004-07: A, Clark Fork at Turah Bridge, near Bonner, Mont.; B, Blackfoot River near Bonner, Mont.; and $C$, Clark Fork above Missoula, Mont. 
Table 3. Equations for estimating unfiltered-recoverable trace-element discharge for Clark Fork at Turah Bridge, near Bonner, Mont., water years 2004-07.

[Abbreviations: $\mathrm{N}$, number of values; $\mathrm{R}^{2}$, coefficient of determination; $\mathrm{p}$-value, significance level; SE, standard error of estimate, in percent; RBCF, retransformation-bias-correction factor; ASQ, arsenic discharge, in tons per day; CDQ, cadmium discharge, in tons per day; CUQ, copper discharge, in tons per day; FEQ, iron discharge, in tons per day; PBQ, lead discharge, in tons per day; MNQ, manganese discharge, in tons per day; ZNQ, zinc discharge, in tons per day; SEDQ, suspended-sediment discharge, in tons per day. Symbol: <, less than]

\begin{tabular}{lccccc}
\hline \multicolumn{1}{c}{ Equation } & $\mathbf{N}$ & $\mathbf{R}^{2}$ & p-value & SE & RBCF \\
\hline & Equations for October 1, 2003-September 30, 2007 & & \\
\hline $\mathrm{ASQ}=0.00295(\mathrm{SEDQ})^{0.531}$ & 53 & 0.88 & $<0.001$ & 34.5 & 1.01 \\
$\mathrm{CDQ}=0.0000143(\mathrm{SEDQ})^{0.765}$ & 53 & .96 & $<.001$ & 26.6 & 1.01 \\
$\mathrm{CUQ}=0.00137(\mathrm{SEDQ})^{0.837}$ & 53 & .96 & $<.001$ & 30.3 & 1.01 \\
$\mathrm{FEQ}=0.0161(\mathrm{SEDQ})^{1.00}$ & 53 & .98 & $<.001$ & 24.5 & 1.01 \\
$\mathrm{PBQ}=0.0000994(\mathrm{SEDQ})^{0.994}$ & 53 & .97 & $<.001$ & 32.8 & 1.01 \\
$\mathrm{MNQ}=0.00545(\mathrm{SEDQ})^{0.837}$ & 53 & .98 & $<.001$ & 21.5 & 1.00 \\
$\mathrm{ZNQ}=0.00158(\mathrm{SEDQ})^{0.878}$ & 53 & .96 & $<.001$ & 31.2 & 1.01 \\
\hline
\end{tabular}

Table 4. Equations for estimating unfiltered-recoverable trace-element discharge for Blackfoot River near Bonner, Mont., water years 2004-07.

[Abbreviations: $\mathrm{N}$, number of values; $\mathrm{R}^{2}$, coefficient of determination; $\mathrm{p}$-value, significance level; SE, standard error of estimate, in percent; RBCF, retransformation-bias-correction factor; ASQ, arsenic discharge, in tons per day; CDQ, cadmium discharge, in tons per day; CUQ, copper discharge, in tons per day; FEQ, iron discharge, in tons per day; PBQ, lead discharge, in tons per day; MNQ, manganese discharge, in tons per day; ZNQ, zinc discharge, in tons per day; SEDQ, suspended-sediment discharge, in tons per day. Symbol: <, less than]

\begin{tabular}{lccccc}
\hline \multicolumn{1}{c}{ Equation } & $\mathbf{N}$ & $\mathbf{R}^{2}$ & p-value & SE & RBCF \\
\hline & Equation & for October 1, 2003-September 30, 2007 & & & \\
\hline $\mathrm{ASQ}=0.00130(\mathrm{SEDQ})^{0.400}$ & 45 & 0.95 & $<0.001$ & 20.0 & 1.00 \\
$\mathrm{CDQ}=0.0000101(\mathrm{SEDQ})^{0.456}$ & 46 & .91 & $<.001$ & 31.5 & 1.01 \\
$\mathrm{CUQ}=0.000495(\mathrm{SEDQ})^{0.668}$ & 46 & .93 & $<.001$ & 38.4 & 1.01 \\
$\mathrm{FEQ}=0.0178(\mathrm{SEDQ})^{0.951}$ & 46 & .99 & $<.001$ & 21.9 & 1.00 \\
$\mathrm{PBQ}=0.0000265(\mathrm{SEDQ})^{0.931}$ & 46 & .99 & $<.001$ & 21.2 & 1.00 \\
$\mathrm{MNQ}=0.00281(\mathrm{SEDQ})^{0.817}$ & 46 & .98 & $<.001$ & 22.6 & 1.00 \\
$\mathrm{ZNQ}=0.000726(\mathrm{SEDQ})^{0.645}$ & 46 & .97 & $<.001$ & 23.6 & 1.01 \\
\hline
\end{tabular}


Table 5. Equations for estimating unfiltered-recoverable trace-element discharge for Clark Fork above Missoula, Mont., water years 2004-07.

[Abbreviations: $\mathrm{N}$, number of values; $\mathrm{R}^{2}$, coefficient of determination; $\mathrm{p}$-value, significance level; SE, standard error of estimate, in percent; RBCF, retransformation-bias-correction factor; ASQ, arsenic discharge, in tons per day; CDQ, cadmium discharge, in tons per day; CUQ, copper discharge, in tons per day; FEQ, iron discharge, in tons per day; PBQ, lead discharge, in tons per day; MNQ, manganese discharge, in tons per day; ZNQ, zinc discharge, in tons per day; SEDQ, suspended-sediment discharge, in tons per day. Symbol: <, less than]

\begin{tabular}{|c|c|c|c|c|c|}
\hline Equation & $\mathbf{N}$ & $\mathbf{R}^{2}$ & p-value & SE & RBCF \\
\hline \multicolumn{6}{|c|}{ Equations for October 1, 2003-May 31, 2006} \\
\hline $\mathrm{ASQ}=0.00263(\mathrm{SEDQ})^{0.503}$ & 27 & 0.91 & $<0.001$ & 27.9 & 1.01 \\
\hline $\mathrm{CDQ}=0.0000228(\mathrm{SEDQ})^{0.657}$ & 27 & .93 & $<.001$ & 31.1 & 1.01 \\
\hline $\mathrm{CUQ}=0.00218(\mathrm{SEDQ})^{0.704}$ & 27 & .93 & $<.001$ & 33.1 & 1.01 \\
\hline $\mathrm{FEQ}=0.0218(\mathrm{SEDQ})^{0.945}$ & 27 & .99 & $<.001$ & 15.6 & 1.00 \\
\hline $\mathrm{PBQ}=0.000163(\mathrm{SEDQ})^{0.842}$ & 27 & .96 & $<.001$ & 28.8 & 1.01 \\
\hline $\mathrm{MNQ}=0.00929(\mathrm{SEDQ})^{0.723}$ & 27 & .95 & $<.001$ & 27.0 & 1.01 \\
\hline $\mathrm{ZNQ}=0.00324(\mathrm{SEDQ})^{0.711}$ & 27 & .94 & $<.001$ & 29.6 & 1.01 \\
\hline \multicolumn{6}{|c|}{ Equations for June 1, 2006-September 30, 2007} \\
\hline $\mathrm{ASQ}=0.00133(\mathrm{SEDQ})^{0.604}$ & 26 & .92 & $<.001$ & 31.7 & 1.01 \\
\hline $\mathrm{CDQ}=0.0000229(\mathrm{SEDQ})^{0.672}$ & 26 & .88 & $<.001$ & 44.1 & 1.02 \\
\hline CUQ $=0.00256(\mathrm{SEDQ})^{0.694}$ & 26 & .88 & $<.001$ & 44.9 & 1.02 \\
\hline $\mathrm{FEQ}=0.0233(\mathrm{SEDQ})^{0.879}$ & 26 & .97 & $<.001$ & 27.7 & 1.01 \\
\hline $\mathrm{PBQ}=0.000282(\mathrm{SEDQ})^{0.754}$ & 26 & .90 & $<.001$ & 43.3 & 1.01 \\
\hline $\mathrm{MNQ}=0.00562(\mathrm{SEDQ})^{0.752}$ & 26 & .95 & $<.001$ & 30.9 & 1.01 \\
\hline $\mathrm{ZNQ}=0.00337(\mathrm{SEDQ})^{0.739}$ & 26 & .90 & $<.001$ & 43.8 & 1.01 \\
\hline
\end{tabular}

\section{Estimated Loads Transported through Milltown Reservoir}

Patterns in daily loads transported past the three monitoring sites aid in understanding the magnitude, duration, and source of constituent transport in response to variations in streamflow or reservoir operations. The cumulative net gains or losses of daily loads for an entire year can then be used to describe an annual mass balance of suspended-sediment and trace-element loads transported through Milltown Reservoir during water years 2004-07.

\section{Daily Loads}

Variations of estimated daily suspended-sediment loads transported to and from Milltown Reservoir during water years 2004-07 are shown in figure 6, along with the daily mean streamflow during the period. Values for the two sites upstream from the reservoir (Clark Fork at Turah Bridge and Blackfoot River near Bonner) are summed to represent the total inflow to Milltown Reservoir. The values for Clark Fork above Missoula represent the outflow from the reservoir.
Deposition of sediment in Milltown Reservoir is indicated where the combined inflow of suspended-sediment load to the reservoir plots higher than the suspended-sediment load for Clark Fork above Missoula. Conversely, loss of sediment from Milltown Reservoir is indicated where the suspended-sediment load at Clark Fork above Missoula plots higher than the combined inflow of suspended-sediment load. Daily variations in loads transported to and from the reservoir illustrate periods of no change, deposition, or loss of sediment (and associated trace elements) within Milltown Reservoir. Generally, deposition of material in the reservoir is more likely to occur during low streamflows when velocities are low. Conversely, loss of material is more likely to occur during high streamflows when velocities are high.

Three periods of sustained drawdown are shown in figure 6 to indicate when the pool in Milltown Reservoir was lowered substantially for several weeks or more to accommodate either routine maintenance activities or activities associated with preparations for the removal of Milltown Dam. Not shown are periods of short-duration or small drawdowns that may have occurred intermittently for various operational purposes. The first two sustained drawdowns were temporary and occurred during July-August 2004 and October-December 2005. The July-August 2004 drawdown was for routine dam 
maintenance, and the October-December 2005 drawdown was to facilitate the removal of Stimson Dam (fig. 1) on the Blackfoot River (U.S. Environmental Protection Agency, written commun., May 2004). The third drawdown that started on June 1, 2006, is Stage 1 of a permanent drawdown and is part of preparations to remove Milltown Dam (U.S. Environmental Protection Agency, written commun., July 5, 2006).

The patterns in daily streamflow (fig. 6) illustrate a typical snowmelt hydrograph in which streamflow was generally low to moderate during the fall and winter, then increased for several months during spring runoff. Streamflow commonly peaked in May or early June. Streamflows decreased relatively rapidly after the peak; the minimum streamflow of the year generally occurred in late summer. Short-lived precipitation events can produce substantial increases in streamflow at any time, as evidenced by the large increase in November 2006. The difference between the combined inflow to Milltown Reservoir and the outflow from the reservoir at Clark Fork above Missoula was negligible, indicating both the minimal storage capacity of the reservoir and accurate streamflow records for all three sites. The minor differences between combined inflow and outflow could represent a loss of surface water to ground water in the alluvium underlying Milltown Reservoir and the river reaches between the gages and the reservoir, or evaporative loss from the surface of the reservoir.

Variations in estimated daily suspended-sediment loads transported to and from Milltown Reservoir during water years 2004-07 (fig. 6) generally coincided with variations in streamflow. For most of the period before June 1, 2006, differences between the daily suspended-sediment loads transported to and from the reservoir were minor or indicated small amounts of deposition. Suspended-sediment loads spiked occasionally without a concurrent large increase in streamflow, possibly as a result of localized sediment disturbances. However, the outflow of suspended sediment from the reservoir was substantially greater than the combined inflow during the temporary drawdowns in July-August 2004 and October-December 2005. The increase in suspended-sediment load transported out of the reservoir during the temporary drawdowns occurred during low-flow conditions; consequently, these losses of sediment from the reservoir may have resulted from erosion of exposed shoreline sediments or localized disturbances, rather than scour of deeper bottom sediments.

A prominent shift in the quantity of suspended sediment transported from Milltown Reservoir occurred after the start of the Stage 1 drawdown on June 1, 2006. During the entire interval of the Stage 1 drawdown (June 1, 2006-September 30, 2007) within the study period, the daily suspended-sediment load transported from the reservoir was consistently larger than the combined daily suspended-sediment load transported to the reservoir (fig. 6). This pattern persisted for all streamflow conditions and, at times, the loss of sediment from the reservoir was substantial. The sediment losses from the reservoir likely were caused by a combination of factors. Primary processes likely included either erosion of bottom sediments in the shallow reservoir that were susceptible to velocity-induced scour during high flow or channel cutting and bank collapse of exposed sediment as water levels dropped and water drained from the material. Minor factors might have included erosion of shoreline sediment by wind-induced waves or disturbance by construction activities (U.S. Environmental Protection Agency, written commun., 2008).

The transport characteristics for all the unfilteredrecoverable trace-element loads (arsenic, cadmium, copper, iron, lead, manganese, and zinc) estimated for this study were generally similar. Therefore, variations in estimated daily trace-element loads transported to and from Milltown Reservoir during water years 2004-07 are illustrated using copper as a representative example (fig. 7). Similar to suspendedsediment loads, the daily copper loads entering and leaving the reservoir generally coincided with variations in streamflow. Because sediment transport is largely a function of streamflow or localized sediment erosion, and trace elements such as copper are strongly associated with sediment (Lambing, 1991), the temporal variations of daily trace-element loads were similar to those of daily suspended-sediment loads (fig. 6).

For most of the period before June 1, 2006, the differences between daily unfiltered-recoverable copper loads transported to and from Milltown Reservoir were small (fig. 7). However, losses of copper from the reservoir were notable during the temporary drawdowns in July-August 2004 and October-December 2005 (fig. 7) when losses of suspended sediment also occurred (fig. 6).

A prominent shift in the quantity of copper transported out of Milltown Reservoir (fig. 7) occurred after the start of the Stage 1 drawdown on June 1, 2006. During the entire interval of the Stage 1 drawdown within the study period, the daily copper load transported from the reservoir was consistently larger than the combined daily copper load transported to the reservoir. This pattern persisted for all streamflow conditions and, at times, the loss of copper from the reservoir was substantial. The increased loss of copper from the reservoir after June 1, 2006 (fig. 7) paralleled the increased loss of suspended sediment during the same period (fig. 6). A similar pattern of increased loss of load from the reservoir during the Stage 1 drawdown was determined for all the trace elements.

\section{Annual Loads}

Estimated annual loads of suspended sediment and trace elements were determined by summing the estimated daily loads transported past each of the three sampling sites near Milltown Reservoir during water years 2004-07. The mass balance of annual loads was determined as the net difference in annual loads transported to and from the reservoir and was used to indicate whether a cumulative net gain or loss of suspended sediment and trace elements within the reservoir occurred during a given water year (table 6).

If less material is transported annually from Milltown Reservoir than entered (table 6), some of the suspended material entering the reservoir was deposited (net gain, indicated by 


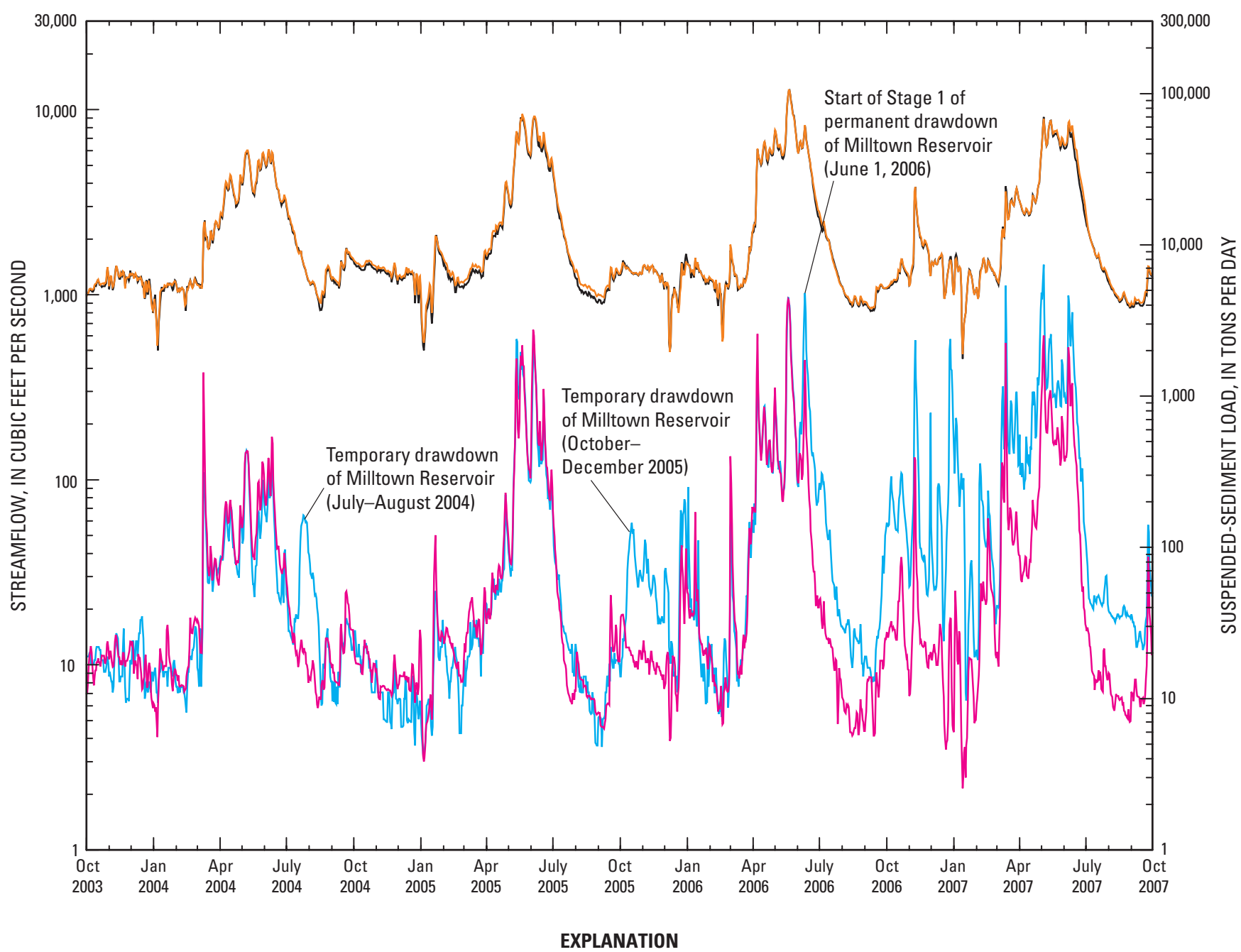

Streamflow

Inflow to Milltown Reservoir-Daily mean streamflow (sum of daily mean streamflows for Clark Fork at Turah Bridge, near Bonner, Mont., and Blackfoot River near Bonner, Mont.)

Outflow from Milltown Reservoir-Daily mean streamflow at Clark Fork above Missoula, Mont.

Suspended-sediment loads

Inflow to Milltown Reservoir-Estimated daily suspended-sediment load (sum of estimated daily suspended-sediment loads for Clark Fork at Turah Bridge, near Bonner, Mont., and Blackfoot River near Bonner, Mont.)

Outflow from Milltown Reservoir-Estimated daily suspended-sediment load at Clark Fork above Missoula, Mont.

Figure 6. Daily mean streamflow and estimated daily suspended-sediment loads transported to and from Milltown Reservoir, water years 2004-07. 


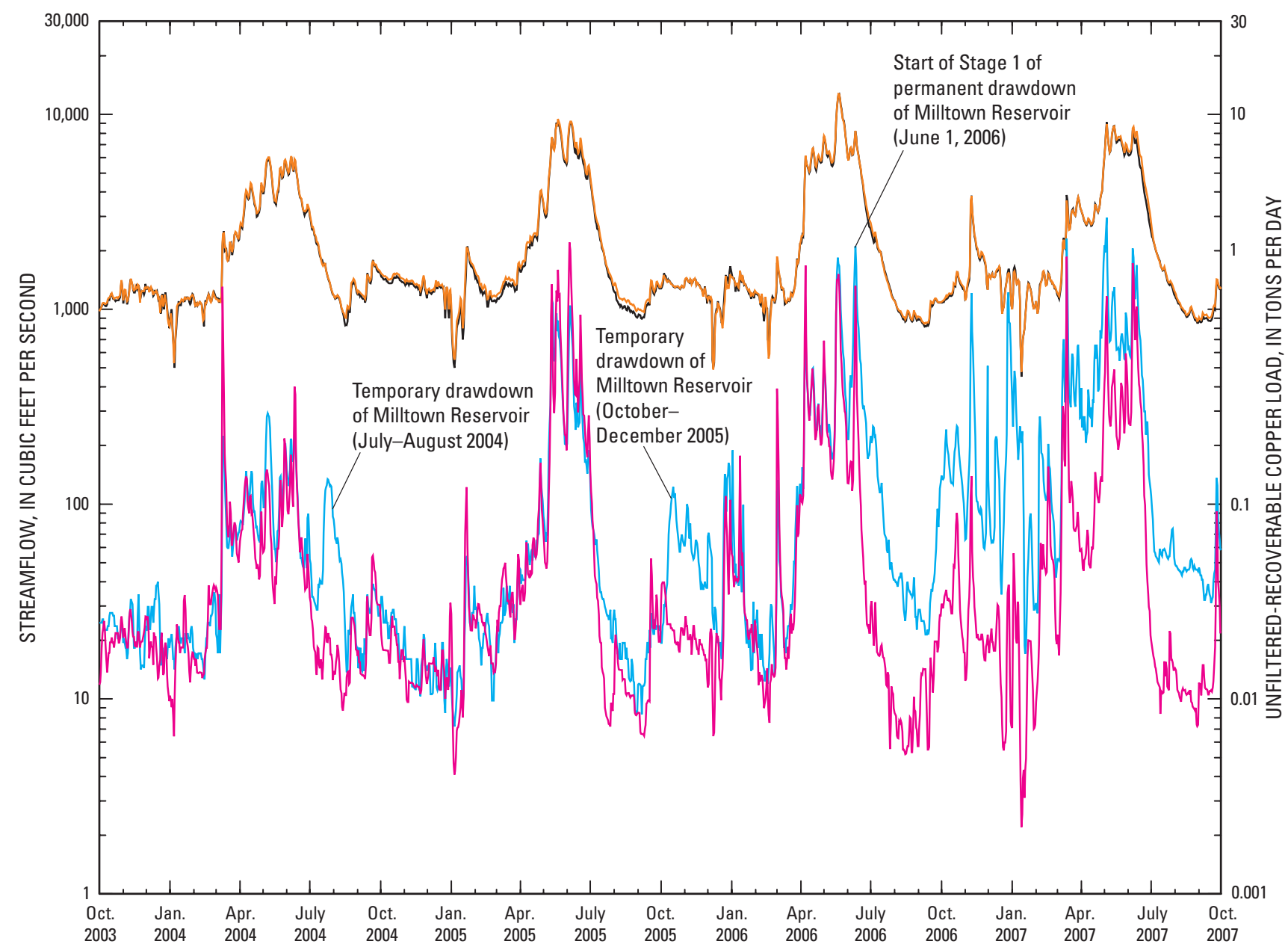

EXPLANATION

\section{Streamflow}

Inflow to Milltown Reservoir-Daily mean streamflow (sum of daily mean streamflows for Clark Fork at Turah Bridge, near Bonner, Mont., and Blackfoot River near Bonner, Mont.)

Outflow from Milltown Reservoir-Daily mean streamflow at Clark Fork above Missoula, Mont.

Unfiltered-recoverable copper loads

Inflow to Milltown Reservoir-Estimated daily unfiltered-recoverable copper load (sum of estimated daily loads for Clark Fork at Turah Bridge, near Bonner, Mont., and Blackfoot River near Bonner, Mont.)

Outflow from Milltown Reservoir-Estimated unfiltered-recoverable copper load at Clark Fork above Missoula, Mont.

Figure 7. Daily mean streamflow and estimated daily unfiltered-recoverable copper loads transported to and from Milltown Reservoir, water years 2004-07. 
Table 6. Annual mean streamflow and estimated annual loads and annual mass balance of suspended sediment and unfilteredrecoverable trace elements transported to and from Milltown Reservoir, water years 2004-07.

[Abbreviations: USGS, U.S. Geological Survey; USGS station numbers: 12334550-Clark Fork at Turah Bridge, near Bonner, Mont.; 12340000-Blackfoot River near Bonner, Mont.; 12340500-Clark Fork above Missoula, Mont.]

\begin{tabular}{|c|c|c|c|c|c|c|c|c|c|}
\hline \multirow[b]{2}{*}{$\begin{array}{l}\text { USGS station number or } \\
\text { summation category }\end{array}$} & \multirow{2}{*}{$\begin{array}{c}\text { Annual } \\
\text { mean } \\
\text { streamflow } \\
\text { (cubic feet } \\
\text { per second) }\end{array}$} & \multicolumn{8}{|c|}{ Estimated annual load, in tons } \\
\hline & & $\begin{array}{l}\text { Suspended } \\
\text { sediment }\end{array}$ & Arsenic & Cadmium ${ }^{1}$ & Copper & Iron & Lead & Manganese & Zinc \\
\hline & \multicolumn{9}{|c|}{ Water year 2004} \\
\hline 12334550 & 872 & 14,100 & 6.40 & 0.0754 & 9.69 & 233 & 1.38 & 38.3 & 13.2 \\
\hline 12340000 & 1,210 & 11,900 & 1.38 & .0129 & 1.41 & 169 & .232 & 14.8 & 1.87 \\
\hline Combined inflow $^{2}$ & 2,080 & 26,000 & 7.78 & .0883 & 11.1 & 402 & 1.61 & 53.1 & 15.1 \\
\hline 12340500 & 2,040 & 22,400 & 6.66 & .110 & 13.0 & 379 & 1.79 & 59.9 & 19.9 \\
\hline \multirow{2}{*}{$\begin{array}{l}\text { Mass balance: net gain }(+) \\
\text { or loss }(-)^{3}\end{array}$} & ${ }^{4}+40$ & $+3,600$ & +1.12 & -.022 & -1.9 & +23 & -.18 & -6.8 & -4.8 \\
\hline & \multicolumn{9}{|c|}{ Water year 2005} \\
\hline 12334550 & 1,140 & 39,600 & 8.63 & 0.142 & 20.5 & 662 & 3.84 & 81.2 & 30.0 \\
\hline 12340000 & 1,220 & 14,000 & 1.40 & .0132 & 1.49 & 195 & .265 & 16.3 & 1.97 \\
\hline Combined inflow ${ }^{2}$ & 2,360 & 53,600 & 10.0 & .155 & 22.0 & 857 & 4.11 & 97.5 & 32.0 \\
\hline 12340500 & 2,260 & 51,100 & 7.59 & .148 & 18.5 & 783 & 3.11 & 87.3 & 28.5 \\
\hline \multirow{2}{*}{$\begin{array}{l}\text { Mass balance: net gain }(+) \\
\text { or loss }(-)^{3}\end{array}$} & ${ }^{4}+100$ & $+2,500$ & +2.4 & +.007 & +3.5 & +74 & +1.00 & +10.2 & +3.5 \\
\hline & \multicolumn{9}{|c|}{ Water year 2006} \\
\hline 12334550 & 1,100 & 33,300 & 8.60 & 0.132 & 18.6 & 555 & 3.23 & 73.5 & 26.7 \\
\hline 12340000 & 1,420 & 38,500 & 1.74 & .0174 & 2.55 & 499 & .659 & 34.3 & 3.28 \\
\hline Combined inflow ${ }^{2}$ & 2,520 & 71,800 & 10.3 & .149 & 21.2 & 1,050 & 3.89 & 108 & 30.0 \\
\hline 12340500 & 2,480 & 97,700 & 11.2 & .255 & 32.7 & 1,300 & 5.57 & 135 & 52.9 \\
\hline \multirow{2}{*}{$\begin{array}{l}\text { Mass balance: net gain }(+) \\
\quad \text { or loss }(-)^{3}\end{array}$} & ${ }^{4}+40$ & $-25,900$ & -.9 & -.106 & -11.5 & -250 & -1.68 & -27 & -22.9 \\
\hline & \multicolumn{9}{|c|}{ Water year 2007} \\
\hline 12334550 & 1,200 & 35,500 & 9.01 & 0.140 & 19.7 & 592 & 3.45 & 78.0 & 28.4 \\
\hline 12340000 & 1,310 & 23,000 & 1.64 & .0160 & 2.03 & 312 & .420 & 24.2 & 2.66 \\
\hline Combined inflow ${ }^{2}$ & 2,510 & 58,500 & 10.6 & .156 & 21.8 & 904 & 3.87 & 102 & 31.1 \\
\hline 12340500 & 2,440 & 188,000 & 16.7 & .453 & 58.8 & 1,880 & 9.67 & 189 & 105 \\
\hline $\begin{array}{l}\text { Mass balance: net gain }(+) \\
\text { or loss }(-)^{3}\end{array}$ & ${ }^{4}+70$ & $-130,000$ & -6.1 & -.297 & -37.0 & -980 & -5.80 & -87 & -74 \\
\hline
\end{tabular}

${ }^{1}$ Estimated cadmium loads for Blackfoot River near Bonner (station 12340000) were based on a regression equation developed from a dataset having a large percentage of censored values (values reported as less than the minimum reporting level). Thus, estimated cadmium loads for this site have greater uncertainty than loads estimated for the other two sites.

${ }^{2}$ Combined inflow is the sum of annual streamflow or load transported to Milltown Reservoir from Clark Fork at Turah Bridge, near Bonner (station 12334550), and Blackfoot River near Bonner (station 12340000).

${ }^{3}$ Mass balance is the difference (net gain or loss) between the annual combined inflow to Milltown Reservoir and the annual streamflow or load transported from Milltown Reservoir. Thus, a net gain (+) indicates net deposition in Milltown Reservoir and a net loss (-) indicates net removal from Milltown Reservoir

${ }^{4}$ The annual mean streamflow for Clark Fork above Missoula (station 12340500) is less than the combined inflow for all years of the study period, which results in a calculated annual net gain of water in Milltown Reservoir. Rather than an actual gain of water, this calculated difference likely represents a loss of surface water to the alluvium underlying Milltown Reservoir and the river reaches between the upstream and downstream gages, plus possible small amounts of evaporative loss from the reservoir surface. 
values of mass balance preceded by a "+"). If more material is transported annually from the reservoir than entered, previously deposited sediment (and associated trace elements) within the reservoir was eroded and put into suspension, added to the suspended material entering the reservoir from upstream sources, and then transported with the streamflow out of the reservoir (net loss, indicated by values of mass balance preceded by a "-“").

In water year 2004, there was an annual net gain of 3,600 tons of suspended sediment in Milltown Reservoir (table 6), which represented about 14 percent of the combined inflow to the reservoir. The net deposition of suspended sediment was possibly the result of below-normal flows during much of the year and a relatively small annual peak flow (fig. 2). Annual net gains also occurred in water year 2004 for arsenic (1.12 tons) and iron (23 tons), representing about 14 percent and 6 percent of the combined inflow of arsenic and iron, respectively, to the reservoir. In contrast, annual net losses from the reservoir occurred in water year 2004 for cadmium (-0.022 ton), copper (-1.9 tons), lead ( -0.18 ton), manganese (-6.8 tons), and zinc (-4.8 tons). These losses, in percent of combined inflow to the reservoir, represented about 25 percent for cadmium, 17 percent for copper, 11 percent for lead, 13 percent for manganese, and 32 percent for zinc. The inconsistent net gains and losses of constituent loads transported through the reservoir in water year 2004 might have been a result of the relatively small loads, which were the smallest of any year during the 2004-07 study period.

In water year 2005, there was an annual net gain of 2,500 tons of suspended sediment in Milltown Reservoir (table 6). The net deposition of suspended sediment in water year 2005 was less than in water year 2004, and represented only about 5 percent of the combined inflow to the reservoir. Annual net gains also occurred in water year 2005 for all of the trace elements, including arsenic (2.4 tons), cadmium (0.007 ton), copper (3.5 tons), iron (74 tons), lead (1.00 ton), manganese (10.2 tons), and zinc (3.5 tons). These amounts of deposited trace elements, in percent of the combined inflow to the reservoir, represented about 24 percent for arsenic, 5 percent for cadmium, 16 percent for copper, 9 percent for iron, 24 percent for lead, 10 percent for manganese, and 11 percent for zinc. Streamflows in water year 2005 were below normal during the spring and late summer and may have had limited capacity to scour reservoir sediment; however, the peak flows in May and June were near normal (fig. 2). Even though streamflow peaks were higher in water year 2005 than 2004, there were no extended periods of sediment or trace-element loss from the reservoir in water year 2005 (figs. 6 and 7). A possible factor contributing to the annual net deposition of suspended sediment and trace elements in water year 2005 might have been the lack of a sustained drawdown of Milltown Reservoir and the associated erosion of reservoir sediment that can occur under such conditions.

In water year 2006, there was a relatively large annual net loss of 25,900 tons of suspended sediment from Milltown Reservoir (table 6), which represented about 36 percent of the combined inflow to the reservoir. Streamflows were above or near normal during the spring (fig. 2), although little or no net loss of sediment from the reservoir was evident during the high-flow period of April-May 2006 (fig. 6). The daily net loss of sediment persisted after the start of the Stage 1 drawdown on June 1, 2006 (fig. 6). The annual net loss of sediment from the reservoir in water year 2006 likely resulted from erosion of reservoir sediment during both the temporary drawdown in October-December 2005 and Stage 1 of the permanent drawdown that continued after June 1, 2006.

The relatively large net loss of sediment from Milltown Reservoir in water year 2006 resulted in an annual net loss for every trace element (table 6). Annual net losses occurred in water year 2006 for arsenic (-0.9 ton), cadmium (-0.106 ton), copper (-11.5 tons), iron (-250 tons), lead (-1.68 tons), manganese (-27 tons), and zinc (-22.9 tons). Iron had the largest annual net loss, in tons, of all the trace elements in water year 2006, although the loss represented only about 24 percent of the combined inflow to the reservoir. The largest annual net losses for trace elements in water year 2006, in percent of combined inflow to the reservoir, occurred for cadmium, copper, lead, and zinc-about 71 percent for cadmium, 54 percent for copper, 43 percent for lead, and 76 percent for zinc. Annual net losses for the other trace elements, in percent of combined inflow, represented about 9 percent for arsenic and 25 percent for manganese.

In water year 2007, there was a large annual net loss of 130,000 tons of suspended sediment from Milltown Reservoir (table 6), which was more than double (about 222 percent) the combined inflow of suspended sediment. The net loss of suspended sediment from the reservoir in water year 2007 was the largest loss during the 2004-07 study period and was more than double the annual net losses of 52,000 and 55,000 tons, respectively, that occurred during the high-flow conditions of water years 1996-97 (Lambing, 1998). The large net loss of suspended sediment transported from the reservoir in water year 2007 is notable in that the annual load (188,000 tons) was substantially less than the annual loads transported in water years 1996 (317,000 tons) and 1997 (445,000 tons) at Clark Fork above Missoula (Lambing, 1998). The large net loss in water year 2007, when the Stage 1 drawdown was in effect for the entire year, indicates the effect of increased erosion of bottom and exposed sediment resulting from lower water levels. Consequently, much of the suspended-sediment load transported from Milltown Reservoir in water year 2007 was derived from eroded reservoir sediment, rather than upstream sources.

The large annual net loss of sediment from Milltown Reservoir in water year 2007 resulted in a large annual net loss for every trace element (table 6). Annual net losses occurred in water year 2007 for arsenic (-6.1 tons), cadmium (-0.297 ton), copper (-37.0 tons), iron (-980 tons), lead (-5.80 tons), manganese (-87 tons), and zinc ( -74 tons). For every trace element, the annual net losses in water year 2007 were the largest of the 2004-07 study period. The annual net losses for copper, lead, and zinc in water year 2007 also were substantially larger 
(double or more) than the annual net losses estimated for those trace elements during water years 1996-97 (Lambing, 1998). Similar to the loads of suspended sediment, the annual loads of copper, lead, and zinc transported in water year 2007 were substantially less than those of water years 1996-97. Iron had the largest annual net loss, in tons, of all the trace elements in water year 2007; the loss represented about 108 percent of the combined inflow to the reservoir. The largest annual net losses of trace elements in water year 2007, in percent of the combined inflow to the reservoir, occurred for cadmium, copper, lead, and zinc_-about 190 percent for cadmium, 170 percent for copper, 150 percent for lead, and 238 percent for zinc. Annual net losses for the other trace elements, in percent of the combined inflow to the reservoir, also were relatively large and represented about 58 percent for arsenic and 85 percent for manganese. The large annual net losses of trace elements in water year 2007 indicate that much of the trace-element load transported from Milltown Reservoir was derived from eroded reservoir sediment, rather than from upstream sources.

\section{Summary and Conclusions}

Milltown Reservoir is a National Priorities List Superfund site in the upper Clark Fork basin of western Montana where sediments enriched in trace elements from historical mining and ore processing have been deposited since the construction of Milltown Dam in 1907. Daily and annual loads of suspended sediment and selected trace elements transported during water years 2004-07 were estimated for two sites upstream and one site downstream from the reservoir, in cooperation with the U.S. Environmental Protection Agency. The estimated loads were used to quantify annual net gains and losses (mass balance) of suspended sediment and trace elements within Milltown Reservoir before and after June 1, 2006, which was the start of the first phase (Stage 1) of a permanent drawdown of the reservoir in preparation for removal of Milltown Dam.

Daily loads of suspended sediment were estimated for water years 2004-07 by using either high-frequency sampling as part of daily sediment monitoring or regression equations relating suspended-sediment discharge to streamflow. Daily loads of unfiltered-recoverable arsenic, cadmium, copper, iron, lead, manganese, and zinc were estimated by using regression equations relating trace-element discharge to suspended-sediment discharge. Regression equations were developed from data for periodic water-quality samples collected during water years 2004-07. The equations were applied to daily records of either streamflow or suspendedsediment discharge to produce estimated daily loads.

Streamflows during water years 2004-07 generally were below or near normal. Annual mean streamflows during the study period were only 70 to 86 percent of the long-term mean annual streamflow. Similarly, annual instantaneous peak streamflows during the study period were only 47 to 83 percent of the long-term mean annual peak streamflow.

Variations in estimated daily suspended-sediment loads transported to and from Milltown Reservoir during water years 2004-07 generally coincided with variations in streamflow. For most of the period before June 1, 2006, differences between the daily suspended-sediment loads transported to and from the reservoir were minor or indicated small amounts of deposition. However, the outflow of suspended sediment from the reservoir was substantially greater than the combined inflow during temporary drawdowns of the reservoir in JulyAugust 2004 and October-December 2005. A prominent shift in the quantity of suspended sediment transported from the reservoir occurred after the start of the Stage 1 drawdown on June 1, 2006. During the entire interval of the Stage 1 drawdown (June 1, 2006-September 30, 2007) within the study period, the daily suspended-sediment load transported from the reservoir was consistently larger than the combined daily suspended-sediment load transported to the reservoir. This pattern persisted for all streamflow conditions and, at times, the loss of sediment from the reservoir was substantial.

The transport characteristics were generally similar for all the unfiltered-recoverable trace-element loads estimated for this study. Therefore, variations in estimated daily traceelement loads transported to and from Milltown Reservoir during water years 2004-07 are illustrated using copper as a representative example. Similar to suspended-sediment loads, daily copper loads transported to and from the reservoir generally coincided with variations in streamflow. For most of the period before June 1, 2006, the differences between daily copper loads transported to and from the reservoir were small. However, losses of copper from the reservoir were notable during the temporary drawdowns in July-August 2004 and October-December 2005 when losses of suspended sediment also occurred.

A prominent shift in the quantity of copper transported from Milltown Reservoir occurred after the start of the Stage 1 drawdown on June 1, 2006. During the entire interval of the Stage 1 drawdown within the study period, the daily copper load transported from the reservoir was consistently larger than the combined daily copper load transported to the reservoir. This pattern persisted for all streamflow conditions and, at times, the loss of copper from the reservoir was substantial. The increased loss of copper from the reservoir after June 1, 2006, paralleled the increased loss of suspended sediment during the same period. A similar pattern of increased loss of load from the reservoir during the Stage 1 drawdown was determined for all the trace elements.

Estimated annual loads of suspended sediment and trace elements were determined by summing the estimated daily loads transported past each of the three monitoring sites near Milltown Reservoir during water years 2004-07. The mass balance of annual loads was determined as the net difference in annual loads transported to and from Milltown Reservoir and was used to indicate whether a cumulative net gain or loss 
of suspended sediment and trace elements within the reservoir occurred during a given water year.

In water year 2004, there was an annual net gain of 3,600 tons of suspended sediment in Milltown Reservoir, which represented about 14 percent of the combined inflow to the reservoir. Annual net gains also occurred in water year 2004 for arsenic (1.12 tons) and iron (23 tons), representing about 14 percent and 6 percent of the combined inflow of arsenic and iron, respectively, to Milltown Reservoir. In contrast, there were annual net losses from the reservoir in water year 2004 for cadmium (-0.022 ton), copper (-1.9 tons), lead ( -0.18 ton), manganese ( -6.8 tons), and zinc ( -4.8 tons). These net losses, in percent of combined inflow, represented about 25 percent for cadmium, 17 percent for copper, 11 percent for lead, 13 percent for manganese, and 32 percent for zinc. The inconsistent net gains and losses of constituent loads transported through the reservoir in water year 2004 might have been a result of the relatively small loads, which were the smallest of any year during the 2004-07 study period.

In water year 2005, there was an annual net gain of 2,500 tons of suspended sediment in Milltown Reservoir. The net deposition of suspended sediment in water year 2005 was less than in water year 2004, and represented only about 5 percent of the combined inflow to the reservoir. Annual net gains also occurred in water year 2005 for all of the trace elements, including arsenic (2.4 tons), cadmium (0.007 ton), copper (3.5 tons), iron (74 tons), lead (1.00 ton), manganese (10.2 tons), and zinc (3.5 tons). The net deposition of trace elements, in percent of the combined inflow to the reservoir, represented about 24 percent for arsenic, 5 percent for cadmium, 16 percent for copper, 9 percent for iron, 24 percent for lead, 10 percent for manganese, and 11 percent for zinc. A possible factor contributing to the annual net deposition of suspended sediment and trace elements in water year 2005 might have been the lack of a sustained drawdown of the reservoir.

In water year 2006, there was a relatively large annual net loss of 25,900 tons of suspended sediment from Milltown Reservoir, which represented about 36 percent of the combined inflow to the reservoir. Streamflows were above or near normal during the spring, although little or no net loss of sediment from the reservoir was evident during the high-flow period of April-May 2006. The daily net loss of sediment persisted after the start of the Stage 1 drawdown on June 1, 2006. The annual net loss of sediment from the reservoir in water year 2006 likely resulted from erosion of reservoir sediment during both the temporary drawdown in October-December 2005 and Stage 1 of the permanent drawdown that continued after June 1, 2006.

The relatively large net loss of sediment from Milltown Reservoir in water year 2006 resulted in an annual net loss for every trace element. Annual net losses occurred in water year 2006 for arsenic (-0.9 ton), cadmium (-0.106 ton), copper ( -11.5 tons), iron ( -250 tons), lead ( -1.68 tons), manganese ( -27 tons), and zinc ( -22.9 tons). Iron had the largest annual net loss, in tons, of all the trace elements in water year 2006 , although the loss represented only about 24 percent of the combined inflow to the reservoir. The largest annual net losses of trace elements in water year 2006, in percent of combined inflow to the reservoir, occurred for cadmium, copper, lead, and zinc-about 71 percent for cadmium, 54 percent for copper, 43 percent for lead, and 76 percent for zinc. For the other trace elements, the annual net losses, in percent of combined inflow, represented about 9 percent for arsenic and 25 percent for manganese.

In water year 2007, there was a large annual net loss of 130,000 tons of suspended sediment from Milltown Reservoir, which was more than double (about 222 percent) the combined inflow of suspended sediment. The annual net loss of suspended sediment from Milltown Reservoir in water year 2007 was the largest loss during the 2004-07 study period and was more than double the annual net losses of 52,000 and 55,000 tons, respectively, that occurred during the high-flow conditions of water years 1996-97. The large loss of suspended sediment from Milltown Reservoir in water year 2007 is notable in that the annual load transported (188,000 tons) was substantially less than the annual loads transported in water years 1996 (317,000 tons) and 1997 (445,000 tons) at Clark Fork above Missoula. The large net loss in water year 2007, when the Stage 1 drawdown was in effect for the entire year, indicates the effect of increased erosion of bottom and exposed sediment resulting from lower water levels. Consequently, much of the suspended-sediment load transported from Milltown Reservoir in water year 2007 was derived from eroded reservoir sediment, rather than from upstream sources.

The large annual net loss of sediment from Milltown Reservoir in water year 2007 resulted in a large annual net loss for every trace element. Annual net losses occurred in water year 2007 for arsenic (-6.1 tons), cadmium (-0.297 ton), copper (-37.0 tons), iron ( -980 tons), lead ( -5.80 tons), manganese ( -87 tons), and zinc ( -74 tons). For every trace element, the annual net losses in water year 2007 were the largest of the 2004-07 study period. The annual net losses of copper, lead, and zinc in water year 2007 also were substantially larger (double or more) than the annual net losses estimated for those trace elements during water years 1996-97. Similar to the loads of suspended sediment, the loads of copper, lead, and zinc transported in water year 2007 were substantially less than those of water years 1996-97. Iron had the largest net loss, in tons, of all the trace elements in water year 2007; the loss represented about 108 percent of the combined inflow to the reservoir. The largest annual net losses of trace-element load in water year 2007, in percent of the combined inflow to the reservoir, occurred for cadmium, copper, lead, and zinc-about 190 percent for cadmium, 170 percent for copper, 150 percent for lead, and 238 percent for zinc. Annual net losses of load for the other trace elements, in percent of the combined inflow, also were generally large and represented about 58 percent for arsenic and 85 percent for manganese. The large annual net losses in water year 2007 indicate that much of the trace-element load transported from Milltown Reservoir was derived from eroded reservoir sediment, rather than from upstream sources. 


\section{References Cited}

Cleveland, W.S., 1985, The elements of graphing data: Monterey, Calif., Wadsworth Books, 323 p.

Cleveland, W.S., and McGill, R., 1984, The many faces of a scatterplot: Journal of the American Statistical Association, v. 79 , p. $807-822$.

Dodge, K.A., Hornberger, M.I., and Dyke, J.L., 2005, Waterquality, bed-sediment, and biological data (October 2003 through September 2004) and statistical summaries of data for streams in the Clark Fork basin, Montana: U.S. Geological Survey Open-File Report 2005-1356, 124 p., accessible at $h t t p: / / p u b s . u s g s . g o v / o f / 2005 / 1356 /$.

Dodge, K.A., Hornberger, M.I., and Dyke, J.L., 2006, Waterquality, bed-sediment, and biological data (October 2004 through September 2005) and statistical summaries of data for streams in the Clark Fork basin, Montana: U.S. Geological Survey Open-File Report 2006-1266, 109 p., accessible at $h t t p: / / p u b s . u s g s . g o v / o f / 2006 / 1266 /$.

Dodge, K.A., Hornberger, M.I., and Dyke, J.L., 2007, Waterquality, bed-sediment, and biological data (October 2005 through September 2006) and statistical summaries of long-term data for streams in the Clark Fork basin, Montana: U.S. Geological Survey Open-File Report 2007-1301, 124 p., accessible at http://pubs.usgs.gov/of/2007/1301

Dodge, K.A., and Lambing, J.H., 2006, Quality-assurance plan for the analysis of suspended sediment by the U.S. Geological Survey in Montana: U.S. Geological Survey Open-File Report 2006-1242, 25 p., accessible at http://pubs.water. usgs.gov/ofr2006-1242

Duan, Naihua, 1983, A nonparametric retransformation method: Journal of the American Statistical Association, v. 78 , no. 383 , p. 605-610.

Edwards, T.K., and Glysson, G.D., 1999, Field methods for measurement of fluvial sediment: U.S. Geological Survey Techniques of Water-Resources Investigations, book 3, chap. C2, 89 p., accessible at http://pubs.water.usgs.gov/ twri/.

Friedman, L.C., and Erdmann, D.E., 1982, Quality assurance practices for the chemical and biological analyses of water and fluvial sediments: U.S. Geological Survey Techniques of Water-Resources Investigations, book 5, chap. A6, 181 p., accessible at http://pubs.water.usgs.gov/twri/.
Garbarino, J.R., and Struzeski, T.M., 1998, Methods of analysis by the U.S. Geological Survey National Water Quality Laboratory-Determination of elements in whole-water digests using inductively coupled plasma-optical emission spectrometry and inductively coupled plasma-mass spectrometry: U.S. Geological Survey Open-File Report 98-165, $101 \mathrm{p}$.

Guy, H.P., 1969, Laboratory theory and methods for sediment analysis: U.S. Geological Survey Techniques of WaterResources Investigations, book 5, chap. C1, 58 p., accessible at http://pubs.water.usgs.gov/twri/.

Hoffman, G.L., Fishman, M.J., and Garbarino, J.R., 1996, Methods of analysis by the U.S. Geological Survey National Water Quality Laboratory-In-bottle digestion of whole-water samples: U.S. Geological Survey Open-File Report 96-225, 28 p.

Horowitz, A.J., Demas, C.R., Fitzgerald, K.K., Miller, T.L., and Rickert, D.A., 1994, U.S. Geological Survey protocol for the collection and processing of surface-water samples for the subsequent determination of inorganic constituents in filtered water: U.S. Geological Survey Open-File Report 97-669, 84 p.

Jones, B.E., 1987, Quality control manual of the U.S. Geological Survey's National Water Quality Laboratory: U.S. Geological Survey Open-File report 87-457, 17 p.

Koch, R.W., and Smillie, G.M., 1986, Bias in hydrologic prediction using log-transformed regression models: Water Resources Bulletin, v. 22, p. 717-723.

Lambing, J.H., 1991, Water quality and transport characteristics of suspended sediment and trace elements in streamflow of the upper Clark Fork basin from Galen to Missoula, Montana, 1985-90: U.S. Geological Survey WaterResources Investigations Report 91-4139, 73 p.

Lambing, J.H., 1998, Estimated 1996-97 and long-term average annual loads for suspended sediment and selected trace metals in streamflow of the upper Clark Fork basin from Warm Springs to Missoula, Montana: U.S. Geological Survey Water-Resources Investigations Report 98-4137, 35 p.

Lambing, J.H., comp., 2006, Quality assurance plan for waterquality activities of the U.S. Geological Survey Montana Water Science Center: U.S. Geological Survey Open-File Report 2006-1275, 39 p., accessible at http://pubs.usgs.gov/ of/2006/1275 
Maloney, T.J., ed., 2005, Quality management system, U.S. Geological Survey National Water Quality Laboratory: U.S. Geological Survey Open-File Report 2005-1263, version 1.3, November 9, 2005, chapters and appendixes [variously paged], accessible at http://pubs.usgs.gov/ of/2005/1263/.

Porterfield, George, 1972, Computation of fluvial-sediment discharge: U.S. Geological Survey Techniques of WaterResources Investigations, book 3, chap. C3, 66 p.

Pritt, J.W., and Raese, J.W., 1995, Quality assurance/quality control manual, National Water Quality Laboratory: U.S. Geological Survey Open-File Report 95-443, 35 p.

Rantz, S.E., and others, 1982, Measurement and computation of streamflow (volumes 1 and 2): U.S. Geological Survey Water-Supply Paper 2175, 2 v., 631 p.

U.S. Environmental Protection Agency, 2004, Milltown Reservoir Sediments Operable Unit of the Milltown Reservoir/ Clark Fork River Superfund Site-Record of Decision, Part 2: Decision Summary, 141 p., accessible at $h t t p: / / w w w$. epa.gov/region $8 /$ superfund/sites/mt/milltown/mrsrod.html

U.S. Geological Survey, variously dated, National field manual for the collection of water-quality data: U.S. Geological Survey Techniques of Water-Resources Investigations, book 9, chaps. A1-A9, accessible at http://pubs.water.usgs. gov/twri/.

Ward, J.R., and Harr, C.A., eds., 1990, Methods for collection and processing of surface-water and bed-material samples for physical and chemical analyses: U.S. Geological Survey Open-File Report 90-140, 71 p.

White, M.K., Shields, R.R., and Dodge, K.A., 1998, Surfacewater quality-assurance plan for the Montana District of the U.S. Geological Survey: U.S. Geological Survey Open-File Report 98-173, 54 p. 
Publishing support provided by:

Helena Publishing Service Center

For more information concerning this publication, contact:

Director, USGS Montana Water Science Center

3162 Bozeman Ave.

Helena, MT 59601

(406) 457-5900

Or visit the Montana Water Science Center Web site at: http://mt.water.usgs.gov 


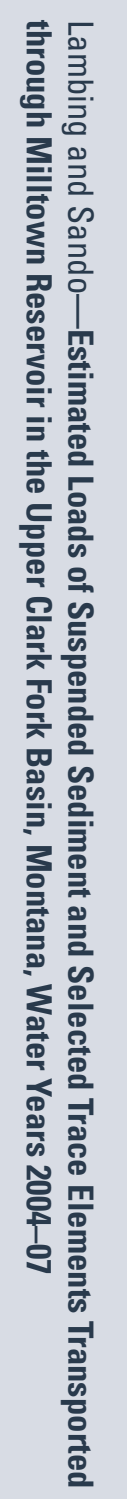

8 Printed on recycled paper 